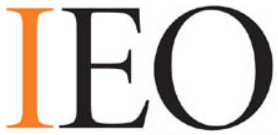

EVALUATION REPORT

Independent Evaluation Office of the International Monetary Fund

\title{
Structural Conditionality in IMF-Supported Programs
}


Established in July 2001, the Independent Evaluation Office (IEO) provides objective and independent evaluation on issues related to the IMF. The IEO operates independently of IMF management and at arm's length from the IMF's Executive Board. Its goals are to enhance the learning culture within the IMF, strengthen the IMF's external credibility, promote greater understanding of the work of the IMF throughout the membership, and support the Executive Board's institutional governance and oversight responsibilities. For further information on the IEO and its work program, please see its website (www.ieo-imf.org) or contact the IEO at +1-202 623-7312 or at info@ieo-imf.org. 

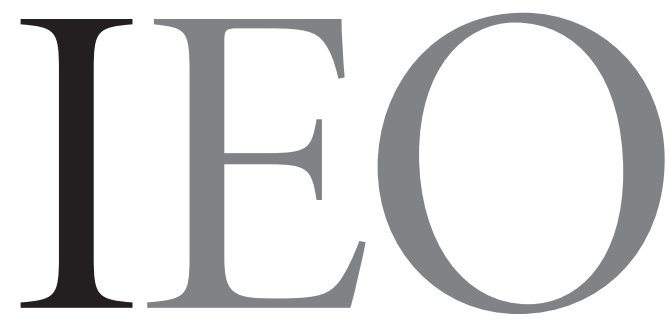

EVALUATION REPORT

Independent Evaluation Office of the International Monetary Fund

Structural Conditionality in IMF-Supported Programs 
(C) 2008 International Monetary Fund

Production: IMF Multimedia Services Division

$$
\text { Lai Oy Louie }
$$

\section{Cataloging-in-Publication Data}

Structural conditionality in IMF-supported programs / [prepared by a team led by Ruben Lamdany and A. Javier Hamann] - [Washington, D.C.] : Independent Evaluation Office of the International Monetary Fund, 2007.

p. $\quad \mathrm{cm} .-($ Evaluation report)

Includes bibliographical references.

ISBN 978-58906-702-8

1. International Monetary Fund - Evaluation. 2. Conditionality (International relations) 3. Structural adjustment (Economic policy) I. Lamdany, Ruben, 1954- II. Hamann, A. Javier. III. International Monetary Fund. Independent Evaluation Office. IV. Evaluation report (International Monetary Fund. Independent Evaluation Office)

HG3118.5.I58 S7783 2007

Price: US\$25.00

Please send orders to:

International Monetary Fund, Publication Services

700 19th Street, N.W., Washington, D.C. 20431, U.S.A.

Tel.: (202) 623-7430 Telefax: (202) 623-7201

E-mail: publications@imf.org

Internet: www.imf.org 


\section{Contents}

Foreword

Abbreviations $\underline{\text { ix }}$

Executive Summary

I Introduction $\underline{2}$

2

Methods and Data $\quad \underline{3}$

3

Structural Conditionality: Structure and Effectiveness

A. The Characteristics of Structural Conditions in

IMF-Supported Programs

B. Compliance with Structural Conditions

C. How Effective Is Structural Conditionality in Fostering Structural Reforms

D. The Determinants of Effectiveness

A. The 2000 Interim Guidance Note and the 2002

Conditionality Guidelines

B. Volume and Composition of Conditionality: What Happened in Practice and Why?

Boxes

1. Structural Conditionality: Views from National Authorities

2. Structural Conditionality: Views from Civil Society

Figures

1. Distribution of Structural Conditionality by Economic Sector

2. Average Number of Structural Conditions Per Program Year, 1995-2004 
Tables

1. Examples of Structural Conditionality, by Type of Condition and Structural Depth (SD)

2. Distribution of Structural Conditions, by Depth, Program, and Type of Monitoring Instrument in the 43 Case Studies

3. Compliance with Structural Conditionality, by Depth and Type of Program

4. Progress in Structural Reform in the Areas Supported by Structural Conditionality

5. Overlapping IMF-WB Conditionality in PrivatizationRelated Conditions in PRGF Programs

Statement by the Managing Director, iMf Staff Response, IEO Comments on Management and Staff Responses, AND the Chair's Summing UP

Statement by the Managing Director

IMF Staff Response

IEO Comments on Management and IMF Staff Responses

The Chair's Summing Up

\section{CD-ROM}

The following are included in the accompanying CD-ROM and are also available on the IEO Website at www.ieo-imf.org.

Main Report (English, French, and Spanish)

Background Documents (English)

Statements and Responses from IMF Management and Staff and the IEO (English, French, and Spanish)

Summing Up of Executive Board Discussion (English, French, and Spanish) 
The following conventions are used in this publication:

- In tables, a blank cell indicates "not applicable," ellipsis points ( . . ) indicate "not available," and 0 or 0.0 indicates "zero" or "negligible." Minor discrepancies between sums of constituent figures and totals are due to rounding.

- An en dash (-) between years or months (for example, 2005-06 or JanuaryJune) indicates the years or months covered, including the beginning and ending years or months; a slash or virgule (/) between years or months (for example, 2005/06) indicates a fiscal or financial year, as does the abbreviation FY (for example, FY2006).

- "Billion" means a thousand million.

- "Basis points" refer to hundredths of 1 percentage point (for example, 25 basis points are equivalent to $1 / 4$ of 1 percentage point).

- As used in this publication, the term "country" does not in all cases refer to a territorial entity that is a state as understood by international law and practice. As used here, the term also covers some territorial entities that are not states but for which statistical data are maintained on a separate and independent basis.

- Some of the documents cited and referenced in this report were not available to the public at the time of publication of this report. Under the current policy on public access to the IMF's archives, some of these documents will become available five years after their issuance. They may be referenced as EBS/YY/NN and SM/YY/NN, where EBS and SM indicate the series and YY indicates the year of issue. Certain other documents are to become available 10 to 20 years after their issuance, depending on the series. 
This page intentionally left blank 


\section{Foreword}

Against the backdrop of continuing debate over the use and effectiveness of structural conditions, the Independent Evaluation Office undertook an evaluation of the use of structural conditionality in IMF-supported programs. It focused on two distinct issues: the effectiveness of structural conditionality at bringing about lasting economic change and the impact of the 2000 Streamlining Initiative to achieve greater focus in the use of conditionality in Fund arrangements.

The report finds that a significant number of structural conditions are very detailed, not obviously critical, and often felt to be intrusive and to undermine domestic ownership of programs. Most programs failed to explain how so many conditions, and at such a level of detail, are needed to bring about the desired long-lasting reforms. The report also finds that compliance with structural conditionality, at about 50 percent, is low compared to about 85 percent for macroeconomic conditionality. In these circumstances, it is difficult to see how structural conditionality contributes to ensuring adequate safeguards for the use of Fund resources or how it provides assurances to borrowing countries regarding the conditions under which Fund resources would be available to them - the roles envisaged for conditionality in the Fund's Articles of Agreement.

The evaluation finds that the average number of structural conditions in IMF-supported programs has not declined since the launching of the streamlining initiative in 2000 and remains at about 17 conditions per program year. However, progress has been made in that the composition of structural conditionality has changed, showing a significant shift toward core areas of IMF expertise, with marked declines in the share of conditions in trade and privatization and increases in tax policy, public expenditure management and financial sector issues. Yet, about one-third of structural conditions continue to fall in non-core areas. The report finds that the absence of a marked decline in the number of conditions can be attributed in part to the significant room for discretion provided by the conditionality guidelines introduced in 2002 (and the difficulty of applying in practice the criticality criterion it sets) together with the lack of clear guidance provided to staff by Management and the Executive Board.

Improving the design of structural conditionality in IMF-supported programs remains a key challenge for the Fund. The overarching message of the report is that efforts need to concentrate on changing incentives within the institution so that programs are better tailored to countries' technical capacities and political realities and to achieve greater parsimony in the number of conditions and greater focus on core areas of IMF expertisethe original goals of the streamlining initiative. Management and the Board need to provide new impetus to the streamlining initiative by restating their commitment to the achievement of its goals.

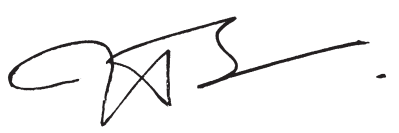

Thomas A. Bernes

Director

Independent Evaluation Office 


\section{Structural Conditionality in IMF-Supported Programs}

This evaluation was prepared by a team led by Ruben Lamdany and A. Javier Hamann. The evaluation was initially launched by a team led by Marcelo Selowsky, who retired in August 2006. The initial team included Philippe Hall, A. Javier Hamann, Emilio Pineda, and Luis Alvaro Sanchez-Barracaldo. Contributions were made by Nils Bjorksten, Markus Berndt, Jeffrey Allen Chelsky, Axel Dreher, Tony Killick, Thomas Reichmann, Marko Skreb, Sophie Brown, Halim Kucur, Camelia Minoiu, Roxana Pedraglio, Teresa Perez, Scott Standley, and Misa Takebe. Administrative support was provided by Arun Bhatnagar, Annette Canizares, and Jeanette Abellera, editorial assistance by Rachel Weaving, and production management by Esha Ray, Emily Ku, and Jeffrey Allen Chelsky. The report was approved by Thomas A. Bernes. 


\title{
Abbreviations
}

\author{
CG Conditionality Guidelines \\ EFF Extended Fund Facility \\ ESAF Enhanced Structural Adjustment Facility \\ EU European Union \\ FSAP Financial Sector Assessment Program \\ GRA General Resources Account \\ HIPC Heavily indebted poor country \\ IEO Independent Evaluation Office (IMF) \\ IGN Interim Guidance Note \\ LIC Low-income country \\ MONA Monitoring of Fund Arrangements \\ PA Prior action \\ PC Performance criterion \\ PEM Public expenditure management \\ PRGF Poverty Reduction and Growth Facility \\ PRSP Poverty Reduction Strategy Paper \\ PSI Policy support instrument \\ SB Structural benchmark \\ SBA Stand-By Arrangement \\ SC Structural conditionality \\ SD Structural depth \\ SOE State-owned enterprise
}


This page intentionally left blank 


\section{Executive Summary}

T his evaluation examines factors influencing the effectiveness of IMF structural conditionality in bringing about structural reform, and assesses the impact of the streamlining initiative launched in 2000 and of the 2002 Conditionality Guidelines. These aimed at reducing the volume and scope of structural conditionality by requiring "parsimony" in the use of conditions and stipulated that conditions must be "critical" to the achievement of the program goals.

The evaluation finds that during the period 1995-2004 there was extensive use of structural conditionality in IMF-supported programs, with an average of 17 conditions per program/year. Most of these conditions had little structural depth and only about half of them were met on time. Compliance was only weakly correlated with subsequent progress in structural reform. Ownership of the reform program by the economic team and by the line ministries in charge of the specific measures was necessary both for compliance and for continuity of the reform. Compliance and effectiveness were higher in the areas of IMF core competency, such as public expenditure management and tax-related issues, and lower in areas such as privatization and reform of the wider public sector.

The streamlining initiative did not reduce the volume of conditionality, partly because structural conditions continued to be used to monitor other initiatives such as donors' support programs and the European Union (EU) accession process. But it helped to shift the composition of conditionality toward IMF core areas and new areas of basic fidu- ciary reform. At the same time, the IMF moved away from controversial areas where it had little impact and that largely fall within the World Bank's areas of expertise. Nonetheless, Fund arrangements still included conditions that seem not to have been critical to program objectives.

Recommendations include reaffirming the need to reduce the volume of structural conditionality. As a practical first step, a notional cap could be set, possibly at four or five conditions per year-half the current average for performance criteria and prior actions. The use of structural benchmarks should be discontinued and measures with low structural content should not be part of conditionality. Normally, conditionality should be restricted to the core areas of IMF expertise. In other critical areas such as the wider public sector, the IMF should play a subsidiary role to that of the World Bank, which has greater expertise in these areas. Explicit Board guidance would be needed when reforms in non-core areas are deemed critical but effective cooperation with the Bank is unlikely to crystallize in time. The Fund should develop a monitoring and evaluation framework linking conditions to reforms and goals, which would provide a more robust basis for assessing programs results. Program documents should explain how the proposed conditionality is critical to achieve explicit objectives. For PRGFs, in particular, program requests should be accompanied by an operational roadmap covering the length of the program, explaining the proposed reforms, their sequencing, and expected impact. 


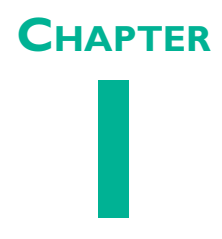

\section{Introduction}

1. Beginning in the mid-1980s, IMF lending was increasingly made conditional on structural reforms that aimed to strengthen the sustainability of macroeconomic adjustment, foster growth, guide the transformation of transition economies, and, more recently, reduce poverty. This trend was associated with the emergence of longer-term facilities for low-income countries and with the challenges being posed by transition economies. The sectoral and thematic coverage of structural conditionality (SC) expanded over time and covered changes in legislation, policies, and the structure of economic incentives, as well as institutional reform.

2. The increased use of SC evoked considerable criticism, including that SC is intrusive and undermines national ownership of policies; that SC lacks prioritization and overwhelms local capacity; that SC is not useful because with strong ownership of reforms it is unnecessary, and without ownership it is unlikely to work; and that the conditions imposed in areas such as trade reform and privatization are ideologically based and often misguided. ${ }^{1}$ Also, many stakeholders, both within and outside the IMF, are opposed to the IMF becoming too involved in reforms that are outside its core areas of competence, and that they argue have resulted in mission creep.

3. In response to these criticisms, in September 2000 the IMF's Managing Director issued an

\footnotetext{
${ }^{1}$ Background Document Chapter I discusses the case for, and main criticisms of, structural conditionality.
}

Interim Guidance Note (IGN) aimed at streamlining SC (IMF, 2000). The IGN emphasized the need for member countries' ownership of the policies supported by Fund arrangements and introduced the requirement that structural conditions be "macrorelevant." Two years later, the Executive Board approved new Conditionality Guidelines (CG) which require "parsimony" in the use of conditions and stipulate that conditions must be "critical to the achievement of program goals" (IMF, 2002). The CG were expected to lead to fewer and more focused structural conditions and to greater involvement of national authorities in program design. Hereafter, the issuance of the IGN and the approval of the CG are together referred to as the streamlining initiative.

4. The evaluation covers programs approved in 1995-2004 and focuses on two sets of issues. First, how has SC worked in bringing about structural reform, i.e., what design characteristics and country conditions make SC more effective? Second, what has been the impact of the streamlining initiative on the number of conditions and on their composition?

5. The report is organized as follows. Chapter II briefly describes the methods and data used in the evaluation. Chapter III provides background on IMF programs and on the use of structural conditions, and presents the main evaluation findings on the effectiveness of SC. Chapter IV discusses the streamlining initiative and examines its impact, and Chapter V concludes with recommendations. 


\section{Methods and Data}

6. A detailed description of the data sources and analytical methods used for the evaluation is given in Background Document Chapters III-V; a brief outline follows here.

7. For this evaluation a structural condition is defined as any program condition that is not a quantitative target related to the financial programming of the arrangement. The analysis is based on information from three overlapping sources:

i) The MONA database. The analysis of compliance with conditionality, and of the numbers and sectoral distribution of SC, was done using the database employed by the IMF for tracking the evolution of arrangements. This database, known as MONA, includes data covering the 7,139 structural conditions for the 216 IMF programs in 94 countries that were approved in 1995-2004.

ii) Desk studies, 1999-2003. Data on a sample of 43 programs approved between 1999 and 2003 were used to analyze the structural depth of conditions, i.e., the degree of structural change that they would bring about if implemented, and their effectiveness in bringing about follow-up reforms. These programs account for 1,567 of the 3,652 conditions in the 103 programs that were approved during that period, and the analysis was based on the 1,306 conditions for which there was information on all the relevant variables. Thirty of the 43 programs were chosen randomly and the remaining 13 were selected from a stratified sample, in order to provide a representative set of countries for the in-depth case studies described below.

iii) In-depth case studies, 1999-2003. In-depth case studies of Fund-supported programs in 13 countries were prepared, to learn about program design, to examine the determinants of effectiveness, and to gather the authorities' views on the process. The 13 case studies were based on interviews with the authorities, other stakeholders in the countries, and IMF and World Bank staff, as well as on a detailed review of a broad set of program-related documents. In addition, country authorities' views were elicited on various aspects of program design, such as negotiation style and the number, detail, and scope of structural conditions. Views from civil society organizations and academics were also sought.

8. A staff survey was undertaken covering issues related to the streamlining initiative and IMF-World Bank cooperation (see Background Document Chapter V). 


\section{Structural Conditionality: Structure and Effectiveness}

9. This section describes the different types of structural conditions and reviews their effectiveness at bringing about structural reform. It begins with a classification of structural conditions according to their legal standing, their sectoral distribution, and the degree of structural change that they would bring about if implemented. This is followed by an analysis of compliance with these conditions and of their effectiveness. The section concludes by discussing factors that may affect the design of SC and its impact on reform.

\section{A. Characteristics of Structural Conditions in IMF-Supported Programs}

10. Of the 216 arrangements that were approved between 1995 and 2004, 119 were financed through the IMF's General Resources Account (99 Stand-ByArrangements (SBAs) and 20 Extended Fund Facilities (EFFs)) and 97 with concessional resources (35 Structural Adjustment Facilities/Enhanced Structural Adjustment Facilities (SAF/ESAFs) and 62 Poverty Reduction and Growth Facilities (PRGFs)); these two groups are henceforth referred to as SBAs and PRGFs respectively. ${ }^{1}$ Of the arrangements that were financed with concessional resources, 70 took place with countries that were eligible for debt reduction under the Heavily Indebted Poor Countries' (HIPC) Initiative. Together, the 216 programs included more than 7,000 structural conditions, of which about 30 percent were prior actions (PAs), 20 percent structural performance criteria (PCs), and 50 percent structural benchmarks (SBs).

11. PAs, PCs, and SBs differ in their legal standing and their timing relative to program discussions

\footnotetext{
1In five cases (Azerbaijan 1996, Pakistan 1997, Yemen 1997, Macedonia 2000, and Sri Lanka 2003), two facilities-the PRGF and the EFF-were used to support the country's program. In these cases, the program framework was given by the PRGF while the EFF resources were used to "top up" those provided under the PRGF. In this evaluation, these programs were counted only once as PRGFs.
}

by the Executive Board. PAs are measures that a member is expected to adopt prior to the approval of an arrangement or the completion of a review (a condition for credit tranche disbursement); they are set by IMF management. Since 2000, program documents sent to the Board have been required to describe the status of PAs (this was not always done before 2000). PCs are conditions approved by the Board that need to be met before disbursements are made under an arrangement. In case of noncompliance with a PC, the Board needs to grant a waiver before a disbursement can be released. The decision to grant a waiver is usually based on assurances that the program is otherwise on track and/ or that remedial actions have been taken. PCs are applied to clearly specified variables or measures, for which timing is considered important and that can be objectively monitored by IMF staff. SBs, on the other hand, are applied to measures that cannot be specified in terms that are objectively monitorable, or to measures where non-implementation of a single component would not be judged sufficient to derail the program. Like PCs, SBs are approved by the Executive Board. Non-compliance with an SB does not automatically lead to an interruption of the program and, therefore, does not require a waiver by the Executive Board. But in response to noncompliance with one or more SBs, management can delay or refuse to submit for the Board's approval an ongoing review of a program if it assesses that the non-compliance would jeopardize the achievement of program objectives. ${ }^{2}$

12. For the purposes of this evaluation, the IEO classified structural conditions into nine sectoral categories, broadly in line with classifications used by IMF staff in internal reviews (see Background Document Chapter III). Four of these sectors-Taxation, Public Expenditure Management (PEM), Financial Sector Reform, and Other Fund Core activities,

\footnotetext{
If the authorities disagree with management on the completion of a review, a Board meeting could still be convened on the subject at the request of an Executive Director. However, in these circumstances, management could withhold its recommendation to the Board to complete the review.
} 
including issues related to trade, exchange rate, and monetary policy - correspond closely to the definition of the Fund's core areas provided by the 2002 CG, and are referred to as "Core" in the remainder of this report. ${ }^{3}$

13. During the evaluation period (1995-2004) about two-thirds of all structural conditions were concentrated in a few core areas of Fund responsibility, with some 20 percent in each of the following areas: Taxation, PEM, and Financial Sector Reform, and 6 percent in other core areas. About half of the remainder focused on state-owned enterprise (SOE) reform and privatization, and the rest were scattered across a large number of sectors where the World Bank has greater expertise than the IMF, including social policies, civil service reform, and regulatory reform (Figure 1).

14. The types of conditions used varied across sectors. Although the general pattern was similar in SBAs and PRGFs, there were some significant differences; notably, financial sector conditionality was more prominent in SBAs, while conditions on PEM were more prominent in PRGFs. Within non-core sectors, the conditions affecting SOE reform and privatization tended to take the form of prior actions and performance criteria, while the conditions affecting the other non-core sectors tended to be SBs.

15. The effects of SC depend not only on the number of conditions but also on the degree of structural change that they would bring about if implemented, and on the durability of this change. This evaluation refers to these characteristics as the structural content or structural depth (SD) of conditions. Table 1 presents examples of SC by type (SB, PC, and PA) and classified and scored according to the following three categories of SD: 4

- Little or No (0). This category includes conditions that would not, by themselves, bring about any meaningful economic changes although they may serve as stepping stones for significant reforms. Examples include the preparation or announcement of plans, strategies, or legislation.

- Limited SD (1). This category includes conditions calling for one-off measures that can be

\footnotetext{
${ }^{3}$ The CG define IMF core areas of responsibility as macroeconomic stabilization, namely, fiscal, monetary and exchange rate policies, including the underlying institutional arrangements and related structural measures; and financial systems issues related to the functioning of both domestic and international financial markets.

${ }^{4}$ The definitions of the categories are intended to be comprehensive and exclusive, i.e., each condition falls into one and only one category. The classification was done with a bias toward ascribing to each condition the highest possible SD category, as is illustrated by the examples in Table 1. About a dozen conditions that did not fit clearly into a single category were classified as having Limited SD. See Background Document Chapter III.
}

Figure I. Distribution of Structural Conditionality by Economic Sector

(In percent of all conditions)
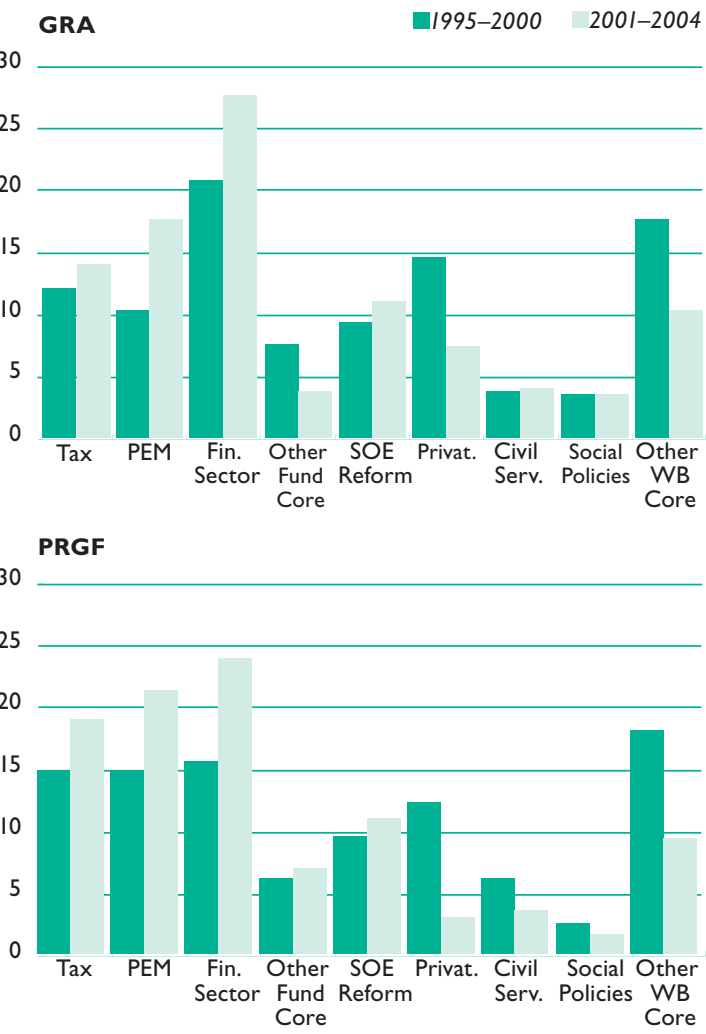

Source: MONA and IEO staff estimates.

expected to have an immediate and possibly significant effect, but that would need to be followed by other measures in order for this effect to be lasting. It encompasses conditions of two main types: those requiring one-off fiduciary measures, and quasi-macro quantitative conditionality. Examples of the former include the publication, by a given date, of the federal budget or the accounts of public enterprises, or the preparation of specific audits. Examples of quasi-macro quantitative conditionality include changes in controlled prices, limits on the growth of the wage bill, or the reduction of arrears of certain public enterprises.

- High SD (2). This category includes conditions that, by themselves, would bring about longlasting changes in the institutional environment. Most of the conditions in this category entail legislative changes (e.g., approval, adoption, or enactment of legislation by a parliament). This category also includes conditions requiring that certain fiduciary measures be taken on a regular and/or permanent basis, even when 
Table I. Examples of Structural Conditionality, by Type of Condition and Structural Depth (SD)

\begin{tabular}{|c|c|c|c|c|c|c|}
\hline \multirow{4}{*}{$\begin{array}{l}\text { SD } \\
\text { High SD (2) }\end{array}$} & \multicolumn{2}{|c|}{ Structural Benchmarks (I) } & \multicolumn{2}{|c|}{ Performance Criteria (2) } & \multicolumn{2}{|c|}{ Prior Actions (3) } \\
\hline & (i) & $\begin{array}{l}\text { Privatization of the electricity generation company } \\
\text { Egasa (Peru } 2002 \text { SBA) (EBS/02/I2 p. 65). }\end{array}$ & (i) & $\begin{array}{l}\text { Privatize Uganda Development Bank (UDB) } \\
\text { (Uganda } 2002 \text { PRGF) (EBS/02/163 p. 68). }\end{array}$ & (i) & $\begin{array}{l}\text { Adopt legislation that allows the effective privatization of } \\
\text { five strategic wineries through an open tender process } \\
\text { (Moldova } 2000 \text { PRGF) (EBS/00/249 p. 38). }\end{array}$ \\
\hline & (ii) & $\begin{array}{l}\text { Congressional approval of the Fiscal Responsibility } \\
\text { Law (Colombia } 2003 \text { SBA) (EBS/02/210 p. 100). }\end{array}$ & (ii) & $\begin{array}{l}\text { Parliament to pass legislation to close duty-free } \\
\text { shops at all land crossing points in border areas } \\
\text { to reduce scope for smuggling and tax evasion } \\
\text { (Albania } 2002 \text { PRGF) (EBS/02/94 p. 63). }\end{array}$ & (ii) & $\begin{array}{l}\text { Approve legislation to permit private sector participation } \\
\text { in construction and operation of roads (Honduras } 1999 \\
\text { ESAF) (SM/04/24 p. 26). }\end{array}$ \\
\hline & (iii) & $\begin{array}{l}\text { Passage of the bill setting up the autonomous Central } \\
\text { Statistical Office by end-September 200I (Sierra } \\
\text { Leone 200I PRGF) (SM/05/I58 p. 4I). }\end{array}$ & (iii) & $\begin{array}{l}\text { Congressional approval of the law for bank } \\
\text { resolution under systemic risk (Dominican } \\
\text { Republic } 2003 \mathrm{SBA} \text { ) (EBS/03/I16 p. I2). }\end{array}$ & (iii) & $\begin{array}{l}\text { Parliament has adopted a revised VAT law consistent with } \\
\text { the MEFP (Macedonia, FYR } 2003 \text { SBA) (EBS/03/5I p. 58). }\end{array}$ \\
\hline \multirow[t]{3}{*}{$\begin{array}{l}\text { Limited SD } \\
\text { (I) }\end{array}$} & (i) & $\begin{array}{l}\text { Establish amount of road sector arrears and reduce } \\
\text { them by C30 billion in first half of } 1999 \text { (Ghana } 1999 \\
\text { ESAF) (EBS/ } 99 / 57 \text { p. } 55) \text {. }\end{array}$ & (i) & $\begin{array}{l}\text { Congressional approval of a Budget bill for } 2004 \\
\text { consistent with the fiscal targets in the program } \\
\text { (Dominican Republic } 2003 \text { SBA) (EBS/03/I16 } \\
\text { p. I2). }\end{array}$ & (i) & $\begin{array}{l}\text { Adoption and passage by parliament of a } 200 \text { I budget fully } \\
\text { consistent with the economic program described in this } \\
\text { memorandum, including associated revisions to the tax } \\
\text { code (Georgia 200I PRGF) (EBS/00/258 p. 56). }\end{array}$ \\
\hline & (ii) & $\begin{array}{l}\text { Issuance of a decree to eliminate existing vacancies } \\
\text { in the public service with immediate effect, and to } \\
\text { close vacancies created by retiring staff, as set out } \\
\text { in paragraph } 17 \text { of the MEP (Colombia } 2003 \text { SBA) } \\
\text { (EBS/02/210 p. 99). }\end{array}$ & (ii) & $\begin{array}{l}\text { Audit of civil servants (Côte d'Ivoire } \\
2002 \text { PRGF) (EBS/02/44 p. 64). }\end{array}$ & (ii) & $\begin{array}{l}\text { Implementation of a VAT at a single rate of } 18 \text { percent } \\
\text { (Mali I999 ESAF) (EBS/99//29 p. 63). }\end{array}$ \\
\hline & (iii) & $\begin{array}{l}\text { Adopt joint action program agreed by Treasury and } \\
\text { SFSA to monitor budget entities' bank accounts, } \\
\text { ensure that payments arrears problems are properly } \\
\text { addressed, and establish a time-bound plan for the } \\
\text { progressive reduction and elimination of arrears } \\
\text { (Mongolia 200I PRGF) (EBS/0I/I66 p. 74). }\end{array}$ & (iii) & $\begin{array}{l}\text { Raise the maximum wage subject to } \\
\text { contributions—used by the CNSS-to ouguiyas } \\
70,000 \text { (Mauritania } 2003 \text { PRGF) (EBS/03/94 } \\
\text { p. } 76 \text { ). }\end{array}$ & (iii) & $\begin{array}{l}\text { Establish financial control departments within the Ministry } \\
\text { of Finance (Estonia } 2000 \text { SBA) (EBS/00//8 p. 74). }\end{array}$ \\
\hline \multirow[t]{3}{*}{$\begin{array}{l}\text { Little or } \\
\text { No SD }(0)\end{array}$} & (i) & $\begin{array}{l}\text { Submit to parliament a draft Law on Financial } \\
\text { Disclosure, requiring regular reporting by senior } \\
\text { elected and appointed officials (Moldova } 2000 \text { PRGF) } \\
\text { (EBS/00/249 p. } 76 \text { ). }\end{array}$ & (i) & $\begin{array}{l}\text { Issue a tender for the privatization of } \\
\text { SONACOS (Senegal } 2003 \text { PRGF) (EBS/03/49 p. } \\
\text { 9l). }\end{array}$ & (i) & $\begin{array}{l}\text { Agree on the main elements of the restructuring of } \\
\text { state-owned commercial banks (SOCBs) to be defined } \\
\text { in consultation with the AsDB and the World Bank (Lao } \\
\text { People's Democratic Republic 200I PRGF) (EBS/0I/53 } \\
\text { p. 76). }\end{array}$ \\
\hline & (ii) & $\begin{array}{l}\text { Agree between the BROU, the BCU, and the } \\
\text { government on a reform plan for BROU (Uruguay } \\
2002 \text { SBA) (SM/05/84 p. 24). }\end{array}$ & (ii) & $\begin{array}{l}\text { Conduct and publish an economic and } \\
\text { environmental analysis, and prepare an action } \\
\text { plan with timetable for the cost-effective } \\
\text { production, distribution, and sale of fuels and } \\
\text { other petroleum products in Ecuador (Ecuador } \\
2003 \text { SBA) (EBS/03/2I p. II). }\end{array}$ & (ii) & $\begin{array}{l}\text { Government to submit to parliament a labor law that } \\
\text { satisfies the conditions specified in paragraph } 24 \text { of the } \\
\text { MEFP (to be monitored in consultation with the World } \\
\text { Bank) (Croatia } 2003 \text { SBA) (EBS/03/3 p. 76). }\end{array}$ \\
\hline & (iii) & $\begin{array}{l}\text { Appoint implementation manager (Interim } \\
\text { Commissioner-General) (Lesotho 200I PRGF) } \\
\text { (EBS/0I//8 p. 53). }\end{array}$ & (iii) & $\begin{array}{l}\text { Bring KESC to point of sale, as detailed in MEFP, } \\
\text { para. } 23 \text { (Pakistan 200I PRGF) (EBS/0I/I97 } \\
\text { p. 83). }\end{array}$ & (iii) & $\begin{array}{l}\text { Announce that the Cocobod will ensure equal access to } \\
\text { its crop financing and warehousing facilities (Ghana } 1999 \\
\text { ESAF) (EBS/99/57 p. } 55 \text { ). }\end{array}$ \\
\hline
\end{tabular}


Table 2. Distribution of Structural Conditions by Depth, Program, and Type of Monitoring Instrument in the 43 Case Studies ${ }^{1}$

\begin{tabular}{|c|c|c|c|c|c|c|c|c|c|c|}
\hline \multirow[b]{2}{*}{$\begin{array}{l}\text { Sector } \\
\text { Number }\end{array}$} & \multirow{2}{*}{$\begin{array}{c}\text { Sector Description } \\
\text { Depth }\end{array}$} & \multicolumn{4}{|c|}{ Number of Conditions } & \multicolumn{4}{|c|}{ Share of Total } & \multirow[b]{2}{*}{$\begin{array}{l}\text { Average } \\
\text { Depth }^{2}\end{array}$} \\
\hline & & All & Low & Limited & High & All & $\begin{array}{l}\text { Low } \\
(\ln p\end{array}$ & $\begin{array}{l}\text { Limited } \\
\text { ercent) }\end{array}$ & High & \\
\hline I & $\begin{array}{l}\text { Tax Policy/Tax } \\
\text { Administration }\end{array}$ & 246 & 83 & 148 & 15 & 19 & 34 & 60 & 6 & 0.72 \\
\hline 2 & PEM & 273 & 97 & 169 & 7 & 21 & 36 & 62 & 3 & 0.67 \\
\hline 3 & Financial Sector & 293 & 154 & 128 & II & 22 & 53 & 44 & 4 & 0.51 \\
\hline 4 & SOE Reform & 147 & 48 & 96 & 3 & II & 33 & 65 & 2 & 0.69 \\
\hline 5 & Privatization & 83 & 53 & 21 & 9 & 6 & 64 & 25 & II & 0.47 \\
\hline 6 & Civil Service Reform & 42 & 24 & 15 & 3 & 3 & 57 & 36 & 7 & 0.50 \\
\hline 7 & Social Policies & 34 & 20 & 12 & 2 & 3 & 59 & 35 & 6 & 0.47 \\
\hline 8 & Other Fund Core & 72 & 25 & 45 & 2 & 6 & 35 & 63 & 3 & 0.68 \\
\hline 9 & $\begin{array}{l}\text { Other World Bank } \\
\text { Core }\end{array}$ & 116 & 54 & 56 & 6 & 9 & 47 & 48 & 5 & 0.59 \\
\hline Total & All Sectors & 1306 & 558 & 690 & 58 & 100 & 43 & 53 & 4 & 0.62 \\
\hline \multirow{2}{*}{ By Program } & GRA & 335 & 167 & 143 & 25 & 26 & 50 & 43 & 7 & 0.58 \\
\hline & PRGF & 971 & 391 & 547 & 33 & 74 & 40 & 56 & 3 & 0.63 \\
\hline \multirow{3}{*}{ By Type } & SB & 646 & 310 & 306 & 30 & 49 & 48 & 47 & 5 & 0.57 \\
\hline & PC & 260 & 99 & 147 & 14 & 20 & 38 & 57 & 5 & 0.67 \\
\hline & PA & 400 & 149 & 237 & 14 & 31 & 37 & 59 & 4 & 0.66 \\
\hline Core vs. & Core & 884 & 359 & 490 & 35 & 68 & $4 \mathrm{II}$ & 55 & 4 & 0.63 \\
\hline Non-Core & Non-Core & 422 & 199 & 200 & 23 & 32 & 47 & 47 & 5 & 0.58 \\
\hline
\end{tabular}

Includes all 1306 fully assessed conditions in the 43 case studies from 1999-2003. Conditions not normalized to correct for program length.

2Calculated as follows: "Low"=0; "Limited"=I; and "High"=2.

Source: MONA, IMF staff reports and IEO staff calculations.

legislation is not needed (often these measures are implemented through regulation). Examples of such measures are similar in substance to conditions with limited SD, but are expected to have more lasting effects. This category also includes conditions with long-lasting structural impact-e.g., implementing a civil service reform or privatization - that may be grounded in pre-existing legislation but that probably could not be undone without new legislation.

16. A review of the full list of structural conditions in the 43 programs found that fewer than 5 percent of the 1,306 conditions had high structural content (Table 2). More than half of the conditions had limited structural content, and the remaining 43 percent had little or none. ${ }^{5}$ Conditions tended to

${ }^{5}$ Two clarifications about the classification. First, the approval of a specific budget law was classified as having Limited SD. While this usually requires legislative action, one year's budget, per se, would not necessarily have a lasting impact in that it needs to occur each year. Second, the submission of legislation to parliament was classified as having low SD because by itself it does not bring about any meaningful economic changes. In certain regimes, most laws submitted to parliament are approved, but the corresponding passage of legislation is captured in the analysis of effectiveness or follow-up reforms. In any case, classifying the submission of laws as having high SD increases the share of this category to about 10 percent of the total, and does not change the rest of the analysis in any significant way. be quite detailed and about one third reached outside the areas of core Fund competency and outside the areas of direct responsibility of the Fund team's main counterparts. The analysis found no clear differences between the types of conditions that were used in PRGFs and in SBAs. It also found that with minor changes, the same conditions were applied as PCs in some cases and as SBs in others. Compared with SBAs, PRGFs had a higher proportion of conditions with limited structural depth (56 percent against 43 percent), partly reflecting the large number of one-off fiduciary actions linked to HIPC and other donor-led initiatives. The average SD of conditions was greater in core than in non-core sectors - on a scale from 0 to 2 they were 0.68 vs. 0.62 for PAs, and 0.71 vs. 0.60 for PCs - indicating that the Fund was supporting more ambitious sectoral reforms in the sectors of its core competence.

17. A sectoral analysis conducted for the 43 countries supports this finding. For each program, the study identified the conditions with the greatest structural depth in each sector. This is a good indicator of how ambitious was the overall sectoral reform program, when sectoral strategies entailed a leading (high depth) condition that was complemented by others with lower SD, probably targeted at less critical aspects of the reform. In about 10 percent of the sectoral reforms, the leading condition had high 
$\mathrm{SD}$, and in only a quarter of cases all conditions had little or no SD. The distribution of the leading conditions according to their SD was similar in PRGFs and SBAs. Again, this indicator points to more ambitious reforms in the core sectors: the leading condition generally had greater SD in core sectors than in non-core sectors. Among the core sectors, 83 percent had at least one condition with high or limited SD, against 61 percent among the non-core sectors.

18. In sum, programs contained a large number of structural conditions dealing with many aspects of policymaking. Often these conditions were quite detailed, even when they covered areas over which the Fund had little expertise and that were outside its core areas of responsibility. While critics may perceive these conditions as intrusive and detracting from government ownership of the reform process, fewer than 5 percent of the structural conditions in fact called for lasting structural reforms and more than 40 percent called only for preparing plans or drafting legislation. Still, almost 60 percent of the structural conditions would have had at least a limited or temporary impact, if complied with, and this share was somewhat greater in the core sectors and in particular in PRGFs. About half of the higher SD conditions were PAs or PCs, and the rest were SBs.

\section{B. Compliance with Structural Conditions}

19. More than half of the conditions (54 percent) were complied with on time (Table 3). ${ }^{6}$ Compliance rates were significantly higher for conditions in the core sectors, particularly among PRGFs (60 percent compliance in core sectors vs. 39 percent in non-core) and among PCs across all types of programs (60 percent compliance in core sectors vs. 37 percent in noncore). Compliance rates were much lower (at less than one-third) for conditions with high SD-probably because these conditions are in general more difficult to implement - and they differed little between structural conditions with limited SD and those with no SD.

\footnotetext{
${ }^{6}$ The compliance rates are similar for the 43 countries shown in Table 3 and for the 7,139 conditions in MONA. These numbers do not include PAs because they are met almost by definition, as the database does not include conditions in programs that have gone off track. Including PAs, the compliance rate would rise to about two-thirds; on the other hand, the rate would be less than half if programs that went off track were included (excluding PAs). According to MONA, about half of the structural conditions that were not met on time were eventually met with delay or met only in part. MONA did not distinguish between these two categories until 2001, and it still does not specify the extent of the delay nor of the compliance. In any case, this information is not available for most of the period of this study. These figures compare with a compliance rate of more than 80 percent for quantitative macro conditions (IMF, 2005a, p. 28).
}

20. The average compliance rate varied widely across countries but it was not significantly correlated with the overall success of the corresponding program. While the overall average was about 50 percent, the compliance rate ranged from about 80 percent in some countries (e.g., Brazil, Guinea, and Mozambique) to less than one-third in others (e.g., Croatia, Ecuador, and Tajikistan). A similar degree of variability was observed in the sample of 13 indepth case studies. On average, PRGFs had higher compliance rates than SBAs. Compliance varied significantly across sectors within individual programs, and in general it was higher in the core sectors.

21. The compliance rate was negatively correlated with the number of sectors covered by a program, but not with the number of conditions in a program. One possible explanation is that the multi-sector coverage of SC taxed the coordination and implementation capacity of the Fund's main counterparts, even when conditions were not inherently very difficult to implement. Also, monetary and fiscal authorities were generally able to oversee and track compliance with large numbers of conditions in areas under their responsibility, but this was more difficult to manage in non-core areas. This is consistent with the findings of the in-depth case studies, which indicate that compliance was higher in areas under the direct control of the authorities managing the reform programs.

22. About one-quarter of all structural conditions had significant or limited SD and were complied with. This proportion was greater in core sectors, in particular for PRGFs, where it reached one-third. The proportion rises only a little (to about 40 percent) when allowing for conditions that were only partially met or met after a delay. By this criterion, the most "successful" structural conditions were PCs in core sectors in PRGFs, half of which were complied with, though this is still a relatively low rate.

23. It is surprising that compliance rates were so low, especially because almost half the conditions did not require policy or institutional changes. It is also surprising to find very little difference in the compliance rates between PCs and SBs, and especially among conditions with different degrees of structural content, since one might expect compliance rates to be linked to how difficult the conditions were to implement. Such low compliance rates pose a reputational risk to the Fund's role in furthering structural reforms.

\section{How Effective Is Structural Conditionality in Fostering Structural Reform?}

24. Fund arrangements are designed to support members' efforts to achieve medium-term external 
Table 3. Compliance with Structural Conditionality, by Depth and Type of Program

\begin{tabular}{|c|c|c|c|c|c|c|c|c|c|c|c|c|c|}
\hline \multicolumn{14}{|c|}{ All Programs } \\
\hline & Structural Depth & \multicolumn{3}{|c|}{ All } & \multicolumn{3}{|c|}{0} & \multicolumn{3}{|c|}{1} & \multicolumn{3}{|c|}{2} \\
\hline $\begin{array}{l}\text { Sector } \\
\text { Number }\end{array}$ & Sector Description & Number & $\begin{array}{c}\text { Percent of } \\
\text { Total }\end{array}$ & $\begin{array}{c}\text { Compliance } \\
\text { Rate }\end{array}$ & Number & $\begin{array}{c}\text { Percent of } \\
\text { Total }\end{array}$ & $\begin{array}{c}\begin{array}{c}\text { Compliance } \\
\text { Rate }\end{array} \\
\end{array}$ & Number & $\begin{array}{c}\text { Percent of } \\
\text { Total }\end{array}$ & $\begin{array}{c}\text { Compliance } \\
\text { Rate }\end{array}$ & Number & $\begin{array}{c}\text { Percent of } \\
\text { Total }\end{array}$ & $\begin{array}{c}\text { Compliance } \\
\text { Rate }\end{array}$ \\
\hline 1 & Tax Policy/Tax Administration & 189 & 21 & 64 & 70 & 17 & 59 & 109 & 24 & 69 & 10 & 23 & 50 \\
\hline 2 & PEM & 174 & 19 & 53 & 67 & 16 & 58 & 101 & 22 & 51 & 6 & 14 & 33 \\
\hline 3 & Financial Sector & 209 & 23 & 56 & III & 27 & 58 & 90 & 20 & 58 & 8 & 18 & 13 \\
\hline 4 & SOE Reform & 77 & 8 & 43 & 24 & 6 & 42 & 52 & II & 44 & 1 & 2 & 0 \\
\hline 5 & Privatization & 51 & 6 & 29 & 33 & 8 & 30 & 12 & 3 & 33 & 6 & 14 & 17 \\
\hline 6 & Civil Service Reform & 32 & 4 & 31 & 18 & 4 & 22 & II & 2 & 45 & 3 & 7 & 33 \\
\hline 7 & Social Policies & 28 & 3 & 43 & 18 & 4 & 44 & 8 & 2 & 50 & 2 & 5 & 0 \\
\hline 8 & Other Fund Core & 53 & 6 & 64 & 20 & 5 & 70 & 31 & 7 & 61 & 2 & 5 & 50 \\
\hline 9 & Other World Bank Core & 93 & 10 & 54 & 48 & 12 & 58 & 39 & 9 & 49 & 6 & 14 & 50 \\
\hline \multirow[t]{3}{*}{ Total } & All Sectors' & 906 & 100 & 54 & 409 & 100 & 53 & 453 & 100 & 56 & 44 & 100 & 32 \\
\hline & Core & 625 & 69 & 58 & 268 & 66 & 59 & 331 & 73 & 60 & 26 & 59 & 35 \\
\hline & Non-Core & 281 & 21 & 43 & $14 \mid$ & 34 & 43 & 122 & 27 & 45 & 18 & 41 & 28 \\
\hline \multicolumn{14}{|c|}{ PRGF } \\
\hline & Structural Depth & \multicolumn{3}{|c|}{ All } & \multicolumn{3}{|c|}{0} & \multicolumn{3}{|c|}{1} & \multicolumn{3}{|c|}{2} \\
\hline $\begin{array}{l}\text { Sector } \\
\text { Number }\end{array}$ & Sector Description & Number & $\begin{array}{l}\text { Percent of } \\
\text { Total }\end{array}$ & $\begin{array}{c}\text { Compliance } \\
\text { Rate }\end{array}$ & Number & $\begin{array}{c}\text { Percent of } \\
\text { Total }\end{array}$ & $\begin{array}{c}\text { Compliance } \\
\text { Rate }\end{array}$ & Number & $\begin{array}{c}\text { Percent of } \\
\text { Total }\end{array}$ & $\begin{array}{c}\text { Compliance } \\
\text { Rate }\end{array}$ & Number & $\begin{array}{l}\text { Percent of } \\
\text { Total }\end{array}$ & $\begin{array}{c}\text { Compliance } \\
\text { Rate }\end{array}$ \\
\hline 1 & Tax Policy/Tax Administration & 162 & 23 & 63 & 58 & 19 & 57 & 99 & 26 & 67 & 5 & 21 & 60 \\
\hline 2 & PEM & 153 & 22 & 56 & 58 & 19 & 60 & 90 & 24 & 54 & 5 & 21 & 20 \\
\hline 3 & Financial Sector & 135 & 19 & 61 & 64 & 21 & 69 & 64 & 17 & 58 & 7 & 29 & 14 \\
\hline 4 & SOE Reform & 58 & 8 & 38 & 16 & 5 & 31 & 41 & II & 41 & I & 4 & 0 \\
\hline 5 & Privatization & 37 & 5 & 30 & 26 & 9 & 27 & II & 3 & 36 & 0 & 0 & \\
\hline 6 & Civil Service Reform & 28 & 4 & 32 & 16 & 5 & 25 & 10 & 3 & 40 & 2 & 8 & 50 \\
\hline 7 & Social Policies & 13 & 2 & 31 & 9 & 3 & 33 & 4 & 1 & 25 & 0 & 0 & \\
\hline 8 & Other Fund Core & 47 & 7 & 70 & 19 & 6 & 68 & 26 & 7 & 73 & 2 & 8 & 50 \\
\hline 9 & Other World Bank Core & 78 & II & 49 & 39 & 13 & 51 & 37 & 10 & 49 & 2 & 8 & 0 \\
\hline \multirow[t]{3}{*}{ Total } & All Sectors & 711 & 100 & 54 & 305 & 100 & 54 & 382 & 100 & 56 & 24 & 100 & 29 \\
\hline & Core & 497 & 70 & 61 & 199 & 65 & 63 & 279 & 62 & 61 & 19 & 79 & 32 \\
\hline & Non-Core & 214 & 30 & 39 & 106 & 35 & 37 & 103 & 23 & 43 & 5 & 21 & 20 \\
\hline \multicolumn{14}{|c|}{ GRA } \\
\hline & Structural Depth & \multicolumn{3}{|c|}{ All } & \multicolumn{3}{|c|}{0} & \multicolumn{3}{|c|}{1} & \multicolumn{3}{|c|}{2} \\
\hline $\begin{array}{l}\text { Sector } \\
\text { Number }\end{array}$ & Sector Description & Number & $\begin{array}{l}\text { Percent of } \\
\text { Total }\end{array}$ & $\begin{array}{c}\text { Compliance } \\
\text { Rate }\end{array}$ & Number & $\begin{array}{c}\text { Percent of } \\
\text { Total }\end{array}$ & $\begin{array}{c}\text { Compliance } \\
\text { Rate }\end{array}$ & Number & $\begin{array}{c}\text { Percent of } \\
\text { Total }\end{array}$ & $\begin{array}{c}\text { Compliance } \\
\text { Rate }\end{array}$ & Number & $\begin{array}{l}\text { Percent of } \\
\text { Total }\end{array}$ & $\begin{array}{c}\text { Compliance } \\
\text { Rate }\end{array}$ \\
\hline $\mathrm{I}$ & Tax Policy/Tax Administration & 27 & 14 & 70 & 12 & 12 & 67 & 10 & 14 & 90 & 5 & 25 & 40 \\
\hline 2 & PEM & 21 & II & 38 & 9 & 9 & 44 & II & 15 & 27 & i & 5 & 100 \\
\hline 3 & Financial Sector & 74 & 38 & 47 & 47 & 45 & 43 & 26 & 37 & 58 & 1 & 5 & 0 \\
\hline 4 & SOE Reform & 19 & 10 & 58 & 8 & 8 & 63 & II & 15 & 55 & 0 & 0 & \\
\hline 5 & Privatization & 14 & 7 & 29 & 7 & 7 & 43 & i & 1 & 0 & 6 & 30 & 17 \\
\hline 6 & Civil Service Reform & 4 & 2 & 25 & 2 & 2 & 0 & 1 & 1 & 100 & I & 5 & 0 \\
\hline 7 & Social Policies & 15 & 8 & 53 & 9 & 9 & 56 & 4 & 6 & 75 & 2 & 10 & 0 \\
\hline 8 & Other Fund Core & 6 & 3 & 17 & 1 & I & 100 & 5 & 7 & 0 & 0 & 0 & \\
\hline 9 & Other World Bank Core & 15 & 8 & 80 & 9 & 9 & 89 & 2 & 3 & 50 & 4 & 20 & 75 \\
\hline \multirow[t]{3}{*}{ Total } & All Sectors & 195 & 100 & 51 & 104 & 100 & 52 & 71 & 100 & 54 & 20 & 100 & 35 \\
\hline & Core & 128 & 18 & 49 & 69 & 23 & 48 & 52 & II & 52 & 7 & 29 & 43 \\
\hline & Non-Core & 67 & 9 & 54 & 35 & II & 60 & 19 & 4 & 58 & 13 & 54 & 31 \\
\hline
\end{tabular}

IIncludes 906 fully assessed conditions in the 43 case study countries excluding all PAs. Conditions not normalized to correct for program length. Source: MONA, IMF staff reports and IEO staff calculations. 
viability and to foster sustainable growth. SC plays a role in providing assurances to members that resources would be available to them upon compliance with agreed policies, in monitoring the member's program, and as a mechanism to interrupt the Fund's support when it becomes apparent that the agreed program goals are unlikely to be achieved.

25. This evaluation examined whether SC was effective in bringing about follow-up structural reforms as well as whether reforms were sustained over time. This is a particularly difficult question because there was no agreed-upon framework to assess results and accountability, and consequently data had not been collected specifically for this purpose. The evaluation used two approaches to address this issue. The first, based on data from the 43 countries, focused largely on reforms in sectors covered by SC; the second, based on the 13 in-depth case studies, looked at the impact of SC at the country level. To avoid intractable causality problems, the analysis asked whether SC had been a step within a broader sectoral reform-i.e., whether compliance with a particular condition was followed by additional reforms in the corresponding sector-but it did not try to establish a direct link. Admittedly, this criterion is a very low threshold for establishing effectiveness, since it links specific conditions to sectoral reforms that may be only marginally (if at all) connected to the corresponding condition, and with reforms that may have taken place without SC. In the 13 in-depth case studies, the evaluation asked about the impact of SC on the country's overall policy framework, and also attempted to identify the determinants of effectiveness. Each of these approaches has limitations, but together they provide useful insights.

26. The sectoral analysis showed only a weak link between compliance with SC and effectiveness at bringing about reform and ensuring its durability. The analysis was conducted by assessing whether further reforms took place to advance the explicit or implicit objectives in sectors covered by SC. An individual condition was deemed effective if reform continued in the corresponding sector following compliance with that condition. For conditions whose compliance completed a reform, mostly conditions with high SD, the effectiveness test was whether reversals had taken place. Additional reforms took place beyond the program in about 55 percent of the sectors covered by SC. Reform stalled in almost 40 percent of the covered sectors and it backtracked in more than 5 percent. Rates of follow-up were somewhat higher in PRGF than in SBA countries, in core sectors than in non-core sectors, and for PCs than for PAs and SBs. ${ }^{7}$

7The 55 percent follow-up figure has a significant upward bias since in many cases the specific conditions were not connected with the sectoral reforms that took place subsequently. This bias
27. The most surprising finding from the sectoral analysis is that the effectiveness figures are almost identical regardless of whether conditions were met, met partially or after a delay, or not met at all. Nor did the analysis find any significant correlation between sectoral average compliance and follow-up reforms (this study's indicator of the effectiveness of $\mathrm{SC})$, either in individual sectors or at the aggregate level, across core and non-core sectors. The study also examined whether SC with greater SD was more effective in ensuring the continuity of reforms, but again it did not find any significant correlation. ${ }^{8}$ In sum, this simple analysis suggests that compliance with SC was not, by itself, a good predictor of lasting sectoral reforms.

28. The 13 in-depth country studies examined whether SC was an effective tool to support economic reform and to strengthen a country's overall economic framework, even if conditionality was only weakly correlated with reform at the sectoral level. SC might be effective even in these circumstances because Fund arrangements, and SC in particular, are designed, negotiated, and implemented mostly with the central bank and the economic ministries - agencies that are generally in charge of the country's overall economic framework. This relationship partly explains the higher compliance with $\mathrm{SC}$ in the core sectors, which are under the direct control of these authorities. Also, Fund arrangements have often been put in place to support goals, such as catalyzing public or private financing, that are not directly connected with sectoral agendas. To address these issues, the 13 studies examined whether the presence of, and compliance with, SC affected the overall policy framework and the success of the program. Table 4 summarizes the assessment for each of the 13 cases (for a more detailed analysis see Background Document Chapter IV). Box 1 reflects the authorities' views in these countries. The views of academics and civil society organizations were also sought; these were largely critical, although in some cases these commentators welcomed the PRSP consultation process (Box 2).

29. Overall, the in-depth analysis found mixed results at the country level in the areas covered by SC

is not present in regard to reversals, where the figure refers to the specific measures that were taken. The analysis was based on staff reports for the first Article IV consultation after expiration of programs, ex post assessments, and requests for a new arrangement, when relevant.

8In fact, sectors that were the object of SC with high SD had a higher than average rate of policy reversals (more than 10 percent, against 6 percent for the whole sample). This may be due to a selectivity bias, i.e., the IMF may be more inclined to ask for conditions with high SD when the authorities' ownership of the reforms is low or when the underlying situation is particularly difficult 
Table 4. Progress in Structural Reform in the Areas Supported by Structural Conditionality

\begin{tabular}{|c|c|c|}
\hline $\begin{array}{l}\text { Degree of } \\
\text { Progress }\end{array}$ & Stand-By Arrangements & PRGFs \\
\hline Satisfactory & $\begin{array}{l}\text { Colombia (2003): High access precautionary type to reduce } \\
\text { market uncertainties and address long-term fiscal rules and } \\
\text { quasi-fiscal issues. Good progress in spite of congressional } \\
\text { opposition to several key measures. (2-year SBA, new } \\
\text { administration, completed) } \\
\text { Romania (200I): Addressed successfully major quasi-fiscal } \\
\text { issues in SOE, particularly in energy, in the context of EU } \\
\text { accession. However, the program was not able to develop } \\
\text { more permanent rules for price adjustments. (2-year SBA, } \\
\text { new administration, high level of conditionality relative to } \\
\text { access, completed) }\end{array}$ & $\begin{array}{l}\text { Armenia (200I): Continuation of a series of post-program } \\
\text { actions focusing on banking as well as fiscal and quasi-fiscal } \\
\text { structural reforms. Good progress in banking and energy } \\
\text { sector reforms. (Program completed) } \\
\text { Pakistan (200I): Program to help debt rescheduling and } \\
\text { support reforms in taxation, financial sector, and energy. } \\
\text { Good progress on banking, trade, and fiscal responsibility } \\
\text { laws. Less so in energy. (Early cancellation at the request of } \\
\text { government) }\end{array}$ \\
\hline Moderate & $\begin{array}{l}\text { Croatia (2003): Short precautionary arrangements to avoid } \\
\text { reversals in the run-up to elections, and in the context } \\
\text { of EU accession. Good progress in labor market reforms, } \\
\text { mixed result on state guarantees and energy sector. } \\
\text { (14-month precautionary, very low access, program not } \\
\text { completed) }\end{array}$ & $\begin{array}{l}\text { Mali (1999): Program subject to a terms of trade shock, } \\
\text { streamlined midway focusing on public expenditure system } \\
\text { in part due to HIPC. Central finances and PEM systems } \\
\text { improved markedly. However, little progress on enlarged } \\
\text { public sector: e.g., cotton and pension systems. (Program } \\
\text { completed) }\end{array}$ \\
\hline Limited & $\begin{array}{l}\text { Ecuador (2003): Ambitious program aimed at BOP } \\
\text { support and passage of significant legislation with } \\
\text { significant opposition by Congress. Very limited progress } \\
\text { on legislation. Most of the measures were fiduciary (e.g., } \\
\text { arrears clearance) in public finances. (I3-month SBA, } \\
\text { program not completed) }\end{array}$ & $\begin{array}{l}\text { Ghana (1999); Cameroon (2000); and Madagascar (200I): } \\
\text { Program development heavily influenced by external and } \\
\text { political shocks that refocused priorities on fiduciary issues } \\
\text { of PEM, particularly as a response to HIPC objectives. } \\
\text { Limited progress on PEM, revenue collections and SOE } \\
\text { management and pricing, particularly in energy. (Only } \\
\text { Madagascar program completed) }\end{array}$ \\
\hline Little Effect & $\begin{array}{l}\text { Dominican Republic (2003): Program aimed at containing } \\
\text { banking and BOP crisis at the end of the administration. } \\
\text { No ownership to tackle structural reforms in taxation } \\
\text { and decaying electricity sector. (2-year SBA, program not } \\
\text { completed) }\end{array}$ & $\begin{array}{l}\text { Kenya (200I): Rather artificial program "pushed from the } \\
\text { outside" to address major governance issues requiring } \\
\text { legislation. (Program not completed) } \\
\text { Lao P.D.R. (200I): Program where strong differences in } \\
\text { strategic directions emerged and became irreconcilable } \\
\text { between staff and authorities. Nam Theun project financing } \\
\text { was successful. (Program not completed) }\end{array}$ \\
\hline
\end{tabular}

and in the reform programs at large. Six programs were judged to have been satisfactory or moderately satisfactory (Armenia, Colombia, Croatia, Mali, Pakistan, and Romania), and the other seven (Cameroon, Dominican Republic, Ecuador, Ghana, Kenya, Lao P.D.R., and Madagascar) to have achieved limited or no progress. Experiences also varied across sectors in each country. SC was more successful in supporting reforms in PEM, taxation, and the financial sector than it was in supporting privatization, the reform of the (extended) public sector, or social sector policies. In general, reducing quasi-fiscal transfers and fiscal vulnerabilities in SOEs proved to be especially challenging. These findings are consistent with those of the sectoral analysis based on the 43 cases.

\section{The Determinants of Effectiveness}

30. What determines whether SC works? While overall SC was not very effective in fostering and sustaining structural reform, the significant variation across cases enables us to draw lessons on design features and country conditions that could enhance effectiveness. This section discusses design features (e.g., sectoral coverage) and country conditions (e.g., ownership of reforms) that may help SC to be more effective.

31. Effectiveness, like compliance, seems to have been higher in the core sectors. This seems to be linked to two interrelated factors. First, these are sectors where Fund staff has solid and widely recognized technical expertise and a good understanding of the implementation constraints faced by the authorities. These factors are conducive to better-designed conditionality that is more likely to be accepted by the authorities and other domestic stakeholders. Second, these sectors are usually under the direct control of the Fund's main counterparts, suggesting that the authorities agreed to these conditions with a better understanding of how they would be implemented.

32. More generally, the case studies point to ownership of the reform program by a strong economic policymaking team as a critical precondition for 


\section{Box I. Structural Conditionality: Views from National Authorities}

The evaluation sought the views of the national authorities involved with the IMF-supported program in the countries covered by the 13 in-depth case studies. These authorities included officials at different levels and in different capacities in each country, mainly those that had negotiated the programs.

Views on program design and the process of negotiation differed, but in general, the authorities held more positive views about Fund conditionality in countries where programs had been more successful. Some, for example in Armenia, Colombia, and Romania, viewed structural conditions as deriving from relatively flexible negotiations, in support of an agenda largely developed domestically, although with varying degrees of support from outside of government. In other countries (e.g., Ghana, Madagascar, and Pakistan), however, the authorities took the view that IMF staff had been unnecessarily inflexible on specific policy requirements. In Ghana, for example, the authorities felt that staff was not flexible enough in the face of shocks that called for adjustments in policies. The Pakistani authorities noted, however, that they had perceived a gradual move toward a more consensual approach since the previous arrangement.

Although the authorities in some countries, notably Madagascar, pointed out that conditionality may have been excessive, this was not a matter of concern in Armenia or Romania - two of the countries that had the largest numbers of conditions. The Romanian authorities noted that neither the very large number of structural conditions (46 conditions per program-year) nor their very detailed nature posed a problem.

In many PRGF countries, the authorities saw SC as being imposed by donors (Kenya) or by the Fund (Lao P.D.R. and Madagascar), noting that the conditions were not adapted to the country's institutional circumstances, implementation capacity, or political constraints. Their comments focused on unrealistic deadlines and on the need to have a meaningful consultation process. In Colombia, Ecuador, Kenya, and Pakistan the authorities explained that staff needed to understand better the political ramifications of conditionality, and that certain conditions may strengthen the opposition's hand, particularly when requiring legislative changes. success. A country's economic team can sometimes use Fund SC as a lever to move a desired reform along. For sustaining a reform, however, broader government ownership - at least ownership of the specific SC by the corresponding implementing bodies - seems to have been a necessary condition. ${ }^{9}$ Among the case study countries, those that made the most progress were those with the strongest government ownership of the reforms that were supported by conditionality (e.g., Armenia, Colombia, Pakistan, and Romania). Those that made least progress were those where the authorities had little interest in the corresponding reforms (e.g., Dominican Republic and Lao P.D.R.), or where the program largely responded to outside forces and lacked the broad support of the authorities (e.g., Kenya).

33. Programs with good results had stronger analytical underpinnings in areas subject to SC. They had relatively well specified objectives and mediumterm roadmaps that dealt with sequencing and that linked specific conditions to the distortions they were addressing (e.g., Armenia and Colombia). This was not the case in most of the PRGFs studied - which may be an important reason why these arrangements had disappointing results. These PRGFs often lacked appropriate medium-term policy roadmaps, and their

\footnotetext{
${ }^{9}$ This study did not test the role of the more generally accepted concept of ownership, which includes support by different constituencies in the population for the policies carried out by the authorities.
}

outlook was surprisingly short run. ${ }^{10}$ They rarely identified priorities and trade-offs for policy changes or specified the appropriate sequencing of reforms beyond a year's time span, and most of their SC involved little long-lasting institutional change. Also, their program documents often failed to explain why a particular set of conditions was critical and why it represented the best available way to achieve the program objectives.

34. Outside the core sectors, close collaboration with the World Bank is critical to provide the necessary knowledge base for reform. Good collaboration with the Bank took place in the financial sector through participation in the Financial Sector Assessment Programs (FSAPs), which yielded detailed diagnostics and technical recommendations, some of which were incorporated in structural conditions. Coordination in other areas was more problematic, as the two institutions pursued different approaches to reform and conditionality. A comparison of privatization conditionality in the sample of PRGF arrangements with parallel Bank operations illustrates these difficulties (Table 5). The comparison found that PRGFs often had precise conditions (with fixed timetables and short horizons), while the Bank's parallel operations had no conditionality, or had conditions that were very general in the context of

\footnotetext{
${ }^{10}$ The lack of a roadmap in PRGFs was also noted in the IEO evaluation of the IMF's role in PRSPs and the PRGF (IEO, 2004).
} 
Table 5. Overlapping IMF-WB Conditionality in Privatization-Related Conditions in PRGF Programs

\begin{tabular}{|c|c|c|c|c|}
\hline Country & Sector & IMF Condition & WB Condition in Parallel Operation & $\begin{array}{l}\text { WB } \\
\text { Operation }\end{array}$ \\
\hline \multirow[t]{2}{*}{ Madagascar } & & $\begin{array}{l}\text { Completion of the bidding process for the sale of the cotton company HASYMA } \\
\text { (PC, } 4^{\text {th }} \text { review, not met). }\end{array}$ & $\ldots$ & \\
\hline & Cotton & $\begin{array}{l}\text { Completion of the bidding process for the privatization of HASYMA (PA, } 5^{\text {th }} \text { review, } \\
\text { met). }\end{array}$ & .. & \\
\hline \multirow[t]{9}{*}{ Ghana } & Cocoa & $\begin{array}{l}\text { Offer Produce Buying Co. (PBC) for sale (PC, not met on time; met subsequently as } \\
\text { PA for the |'st review). }\end{array}$ & $\begin{array}{l}\text { Offer PBC for sale (condition complemented by others } \\
\text { conducive to the sale of PBC). }\end{array}$ & $\begin{array}{l}\text { ERSO II } \\
(5 / 99-6 / 03)\end{array}$ \\
\hline & Electricity & Appoint sales advisor for divestiture of the electricity company (ECG) (PC, met). & $\begin{array}{l}\text { Borrower to send a 'Request for Proposals' to potential } \\
\text { advisors in a short list (condition complemented by others } \\
\text { conducive to the sale of PBC). }\end{array}$ & $\begin{array}{l}\text { ERSO III } \\
(7 / 01-12 / 02)\end{array}$ \\
\hline & Oil & $\begin{array}{l}\text { Offer the Tema Oil Refinery (TOR) for sale (PC, not met on time; met as a PA for } \\
\text { the } 5^{\text {th }} \text { review). }\end{array}$ & $\ldots$ & \\
\hline & & $\begin{array}{l}\text { Cabinet approval of a debt restructuring plan for TOR (PA for the |st review, met). } \\
\text { Complete divestiture of State Transport Co. and cement company GHACEM (PA }\end{array}$ & & \\
\hline & Transport & for program request, met). & $\cdots$ & \\
\hline & Telecom & $\begin{array}{l}\text { Select an advisor for the sale of at least } 10 \text { percent of the government's shares in } \\
\text { Ghana Telecom (PA for the } 2 \text { nd review, met). }\end{array}$ & $\ldots$ & \\
\hline & General & $\begin{array}{l}\text { Provide the IMF with a divestiture work program, including annual targets for } \\
\text { divestiture receipts for 1999-200I (PA for program request, met). }\end{array}$ & $\ldots$ & \\
\hline & General & $\begin{array}{l}\text { Appoint sales advisor for divestiture of Ghana Airways and Ghana Railways (PC, } \\
\text { partially met). }\end{array}$ & ... & \\
\hline & General & $\begin{array}{l}\text { Cabinet approval of a list of government assets valued at not less than US } \$ 50 \text { million } \\
\text { to be sold in } 2001 \text {, including estimated dates of sale (PA for the } 3^{\text {rd }} \text { review, met). }\end{array}$ & $\ldots$ & \\
\hline \multirow[t]{7}{*}{ Mali } & $\begin{array}{l}\text { Water, } \\
\text { Cotton }\end{array}$ & $\begin{array}{l}\text { Launching of the call for bids for the sale of assets of the cotton (CMDT) and water } \\
\text { (OHVN) companies, necessary for the installation of a private operator in the } \\
\text { OHVN zone (PC, met with delay). }\end{array}$ & $\begin{array}{l}\text { Bring to the point of sale all assets belonging to CMDT } \\
\text { and OHVN in the OHVN Zone. }\end{array}$ & $\begin{array}{l}\text { SAC III } \\
(12 / 0 I-6 / 04)\end{array}$ \\
\hline & Transport & $\begin{array}{l}\text { Call for bids for the privatization of the management of Airports of Mali ADM (SB, } \\
\text { not met). }\end{array}$ & ... & \\
\hline & Electricity & Bids for capital of the energy company (EDM) (PC, met with delay). & $\ldots$ & \\
\hline & Manufacturing & $\begin{array}{l}\text { Divest government minority shareholdings in canned products (SOMACO), air } \\
\text { services (MALITAS), chemical products (SMPC), and machinery (SEMA) firms (PA } \\
\text { for program request, met). }\end{array}$ & $\ldots$ & \\
\hline & Tobacco & $\begin{array}{l}\text { Sign agreement for privatization of the national society of tobacco and matches } \\
\text { SONATAM (PA for program request, met). }\end{array}$ & $\ldots$ & \\
\hline & Telecom & $\begin{array}{l}\text { International call for bids to grant at least one cellular telephone operating license } \\
\text { to the private sector (SB, met with delay). }\end{array}$ & $\ldots$ & \\
\hline & General & $\begin{array}{l}\text { Adoption of a } 1999-2002 \text { action plan to reduce the number of non-bank public } \\
\text { enterprises in the government's portfolio from } 33 \text { to } 18 \text { (PA for the program } \\
\text { request, met). }\end{array}$ & ... & \\
\hline \multirow[t]{4}{*}{ Cameroon } & & Resume discussions with the successful bidder for the water company (SNEC) based & $\begin{array}{l}\text { Publication of the tender document for the privatization of } \\
\text { SNEC and two other SOEs. }\end{array}$ & \multirow{4}{*}{\begin{tabular}{|l|} 
SAC III \\
$(6 / 98-3 / 04)$ \\
SAC III \\
$(6 / 98-3 / 04)$ \\
SAC III \\
$(6 / 98-3 / 04)$
\end{tabular}} \\
\hline & Vater & on the evaluation of the offer conducted with World Bank assistance (SB, met). & & \\
\hline & $\begin{array}{l}\text { Telecom } \\
\text { Electricity }\end{array}$ & $\begin{array}{l}\text { Forward to the IMF and the World Bank the Head of State's notification letter } \\
\text { validating the recommendations on privatization of the Inter-ministerial Committee } \\
\text { (CIM) with respect to the final offers of the provisional adjudicators for the privati- } \\
\text { zation of the telecom (CAMTEL) and electricity (SONEL) companies (PA, met). }\end{array}$ & \multirow[t]{2}{*}{$\begin{array}{l}\text { Issuance of the invitation to the most successful bidders } \\
\text { for CAMTEL and three other SOEs to start negotiations. }\end{array}$} & \\
\hline & Telecom & $\begin{array}{l}\text { Issue an invitation to negotiate to the successful bidder of CAMTEL } \\
\end{array}$ & & \\
\hline \multirow[t]{3}{*}{ Pakistan } & Telecom & $\begin{array}{l}\text { Bring telecommunications company PTCL to the point of sale through transparent } \\
\text { and open public offer for sale (SB, not met). }\end{array}$ & \multirow{2}{*}{$\begin{array}{l}\text { Bring to the point of sale the following firms: PTCL, KESC } \\
\text { and five other SOEs. }\end{array}$} & \multirow{2}{*}{$\begin{array}{l}\text { Follow-up } \\
\text { actions } \\
\text { (FY03-05) }\end{array}$} \\
\hline & & Bring electricity company KESC to the point of sale (PC, not met). & & \\
\hline & Electricity & Cabinet decision on KESC privatization strategy (PA for the Ist review, met). & $\begin{array}{l}\text { Cabinet approval of a short- and medium-term strategy } \\
\text { and timetable for privatization focused on the critical large } \\
\text { SOE in power, telecom, banking, oil and gas (not a trigger). }\end{array}$ & $\begin{array}{l}\text { SAC } \\
(6 / 0 I-12 / 0 I)\end{array}$ \\
\hline
\end{tabular}




\section{Box 2. Structural Conditionality: Views from Civil Society}

Civil society organizations have been at the forefront of the criticism of SC. Briefly, their three main lines of criticism are as follows:

- Conditions are typically imposed by donors and not owned by countries, and hence a prerequisite for successful development is missing. Eurodad argues that this imposition overwhelms domestic capacities and undermines whatever local ownership exists for those policies (Eurodad, 2006). Wood and Lockwood (1999), of the Bretton Woods Project, explain that the proliferation of SC and its damaging effect on national ownership has led countries to comply with conditionality only for "tactical reasons" and that after receiving aid, countries reverse the enacted policies. Oxfam has raised concerns about the legitimacy of policies agreed with the IMF on grounds that key sectors of society were not properly consulted or were excluded from program negotiations (Oxfam International, 2004)
- Donors often advocate policies and conditions based on dogma and ideology rather than on evidence. Critics give trade and domestic price liberalization and privatization as examples. Action Aid (2004) discusses the pervasiveness of conditions aimed at privatization of water and electricity services in lower-income countries, despite the absence of evidence that these policies improve access for poor people, accountability to consumers, or cost effectiveness.

- Tying aid to conditions causes unpredictability and volatility in aid disbursements, which reduces the usefulness of aid. To address deeply rooted issues, such as poverty or limited access to health services, a country needs a predictable stream of aid on the basis of which it can plan the necessary programs. Lack of compliance with conditionality disrupts these programs. A recent report by the Jubilee Debt Campaign identifies IMF conditions in PRGFs as the main reason for borrowing countries' delays in securing HIPC debt relief (Jubilee Debt Campaign, 2006). a programmatic type of loan with flexible tranching arrangements. More generally, the Bank was moving toward ex post "supporting success" and emphasizing country ownership of programs rather than setting conditions in advance. Despite these differences, the case studies found productive collaboration at the country level in Armenia, Colombia, Croatia, Pakistan, and Romania. Collaboration was weaker in the Dominican Republic, Lao P.D.R., and Madagascar, where insufficient prior knowledge on structural issues hampered program design.

35. In parallel to their role in supporting stabilization and structural reform, Fund arrangements were used by donors and others as monitoring and signaling mechanisms for other initiatives. For example, they acted as a trigger for HIPC process milestones, served to monitor reforms undertaken toward EU accession and helped to mobilize financing from multilateral development banks, the Paris Club, and official donor agencies. ${ }^{11}$ This role was widely ac-

\footnotetext{
${ }^{11}$ Among the 13 case study countries debt restructuring took place in the Dominican Republic, Ecuador, Kenya, and Pakistan; and Lao P.D.R. was able to mobilize financing for the Nam Theun hydroelectric project. Fund arrangements provided a monitoring framework for the EU accession process, explicitly (e.g., Romania) or implicitly (e.g., Croatia).
}

knowledged, although not always explicitly stated in Board documents. In most instances, the presence of SC was important in allowing the Fund arrangement to play these roles, and sometimes these monitoring and signaling needs were what drove the SC agenda and the timing of the arrangement. Some programs were rushed to enable countries to reach the HIPC decision point by an exogenously set deadline. Sometimes conditions were included which, while important for the monitoring role, were not critical to the explicit program objectives. The proliferation of conditions weakened the authorities' attention to those conditions that called for more critical reforms. In general, Fund arrangements and SC were effective in this role of providing monitoring and signaling.

36. Notwithstanding the successful use of SC as a monitoring and signaling mechanism, their use for this purpose raises important questions. Should this be a legitimate role for Fund arrangements and SC? Should Board documents state that this is a major goal of the arrangement? It appears that there are trade-offs between the role of SC as a signaling or monitoring mechanism and its role in fostering reform. To the extent that such trade-offs are significant, could these other roles be played by other instruments, either new ones or those that already are part of the IMF's toolkit? 


\section{(

\section{The Impact of the Streamlining Initiative}

37. This section reviews the effects of the streamlining initiative. It introduces the Interim Guidance Note (IGN) and the 2002 CG, the two main documents that have regulated the Fund's approach to SC since 2000, and discusses their goals and main requirements. It then examines the factors that affected their implementation in regard to the volume and composition of conditionality.

\section{A. The 2000 Interim Guidance Note and the 2002 Conditionality Guidelines}

38. In 2000, largely in response to the proliferation of SC in the mid-1990s and the criticism that this drew, IMF management issued an IGN. The IGN aimed at strengthening country ownership of reforms and attempted to lay out principles for narrowing the scope of SC through the requirement that structural conditions be "macro relevant." A review of conditionality was subsequently launched and in September 2002 the Executive Board approved the 2002 CG, which replaced both the 2000 IGN and the 1979 Guidelines on Conditionality.

39. The CG re-emphasized the importance of national ownership and of effective coordination with the World Bank, and called for "parsimony" and "criticality" in the use of conditions. It stated that conditions would be established only if they were "of critical importance for achieving the goals of the member's program" and that they "will normally consist of macroeconomic variables and structural measures that are within the Fund's core areas of responsibility."

40. The CG was generally expected to lead to a reduction in the number of conditions. ${ }^{12}$ From the

\footnotetext{
${ }^{12}$ For example, the "Operational Guidance Note on the Conditionality Guidelines"-issued in 2003 and amended in 2006 stated that the 2002 CG would "replace the somewhat weaker standard of macro-relevance in the earlier [IGN]" by a test requiring that any variable selected for formal conditionality must be of "critical importance" in that "if it were not implemented, it is expected that the goals [of the program] would not be achieved." Also, during the most recent review of conditionality, staff noted that "The guidelines were also expected, broadly speaking, to
}

start, however, there was some debate about what criticality implied for the sectoral composition of SC. Though the CG left some room for conditions to be established outside the Fund's core areas of responsibility, it set the expectation that such instances would be exceptional and it required that in these cases staff provide a more detailed explanation of the conditions' critical importance. The CG called for the application of a "lead agency framework" when dealing with reforms outside the Fund's core areas of responsibility. In particular, it stressed the need for close collaboration with the World Bank in establishing and monitoring these reforms. The language of the $\mathrm{CG}$, therefore, left some discretion to allow the Fund to deal with country-specific circumstances.

\section{B. Volume and Composition of Conditionality: What Happened in Practice and Why?}

41. There is no evidence of a reduction in the number of structural conditions following the introduction of the streamlining initiative (Figure 2). The average number of structural conditions per program/year remained at around 17, when comparing the four-year period following the start of the streamlining initiative (2001-04) with the four-year period that preceded it (1997-2000). In PRGF arrangements, this average declined slightly from around 16 to 15 conditions, while in SBAs it rose from 18 to 19 . But none of these changes is statistically significant. Neither did significant changes take place in the shares of PAs, PCs, or SBs in the total number of conditions. These findings are somewhat surprising because the $\mathrm{CG}$ argued that "arrangements supporting longer-term programs will have more

lead to reduced numbers of structural conditions" (IMF, 2005a, p. 14). As for expectations outside the IMF, Abdilina and JaramilloVallejo (2005) note that "The streamlining effort entailed reducing the number of conditions in programs while sharpening their focus" (p. 85). 
Figure 2. Average Number of Structural Conditions Per Program Year, 1995-2004

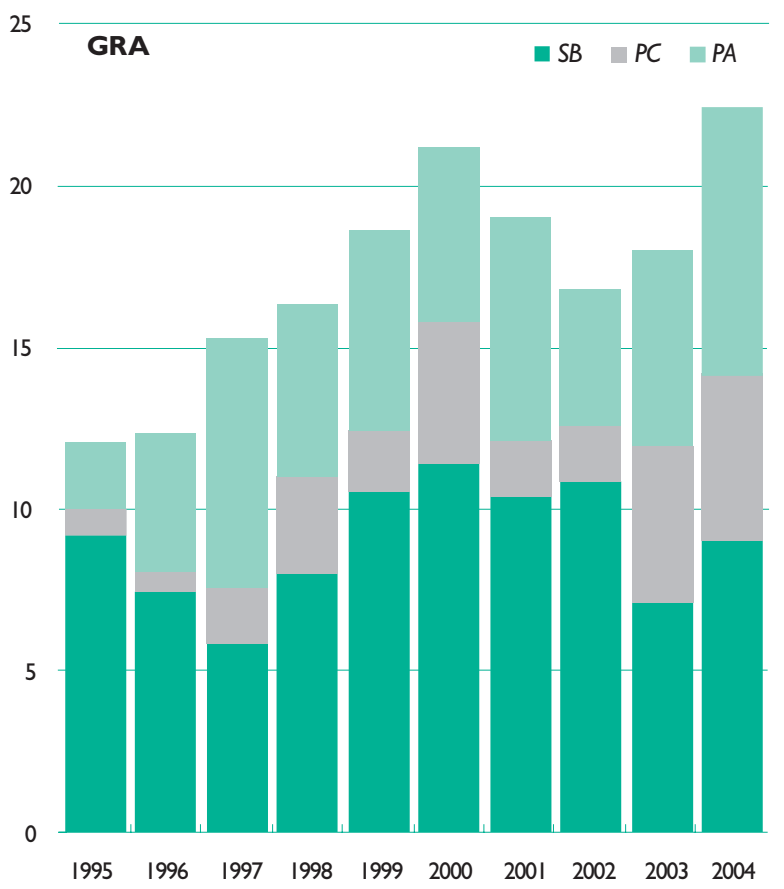

Source: MONA database and IEO staff estimates.

extensive SC [. . .] because structural reforms are more likely to be critical for the achievement of longer-term goals," and it also explained that excessive reliance on PAs could tax implementation capacity and hinder effectiveness.

42. The streamlining initiative did affect the thematic and sectoral composition of structural conditions. Both in PRGF arrangements and SBAs, SC shifted out of privatization of SOE and trade reform toward tax policy and administration, PEM, and financial sector reform. These findings are consistent with internal IMF studies (IMF, 2005a, b) that show that the number of conditions did not decline and that SC shifted toward Fund core areas: economic management and the financial sector. Some of these sectoral shifts reflected a change in approach rather than a response to the underlying economic situation. For example, the analysis in Background Document Chapter II indicates that the number of conditions in financial sector and privatization was correlated with the corresponding level of distortions in the sector. It appears that this relationship shifted at around the time the initiative was launched, i.e., for a given degree of distortion, the number of conditions increased in the financial sector and fell in privatization. In some sectors the $\mathrm{CG}$ reinforced shifts that had begun earlier. For example, in the financial sector the number of conditions began rising

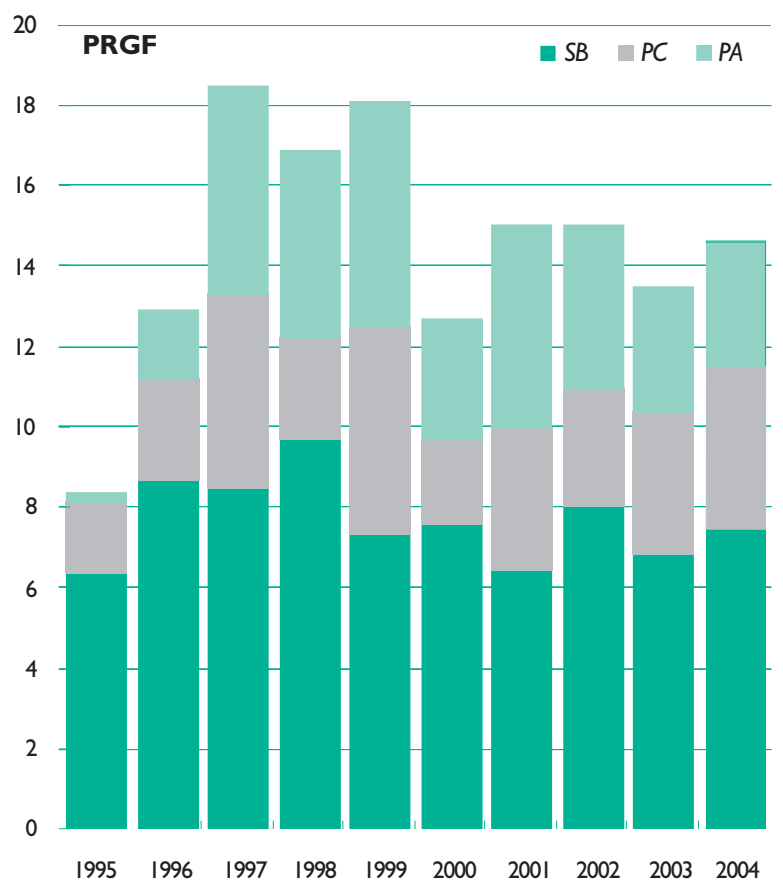

in 1998 , linked to the growing attention being paid to financial sector surveillance after 1997.

43. The streamlining initiative did not lead to better explanations of why conditions, either core or non-core, were critical, nor of how these conditions would contribute to program objectives. Wellspecified medium-term roadmaps were present in PRGFs only in countries whose Poverty Reduction Strategy Paper (PRSP) contained a well-developed medium-term policy assessment. To examine how program documents have justified the conditions being imposed, the evaluation compared documents from a sample of IMF arrangements approved during 2004-05 with those for the 13 in-depth case study programs (approved in 1999-2003). It found that the use of specific structural conditions was no better explained in the recent programs than in the earlier ones. ${ }^{13}$ In most cases, program goals were very broad, the specific measures subject to conditionality were far removed from the ultimate objective they were supposed to serve, and the intermediate goals or mechanisms through which the

\footnotetext{
${ }^{13}$ Good justifications were provided in three of the ten programs (Ukraine, Bulgaria, and Mozambique), but only moderately good explanations were given in another two (Burundi and Georgia), and fairly poor ones in the rest (Republic of Congo, Gabon, Honduras, Peru, and Zambia).
} 
measures would affect the goals were not specified. The more recent PRGFs continued to fall short of providing clear policy roadmaps. Only for Mozambique, whose PRSP has a well developed mediumterm policy assessment framework, was it found that the PRGF documentation conveys an adequate multiyear perspective.

44. The World Bank's sectoral distribution of conditionality changed in the same direction as the Fund's over the same period, and indeed the Bank's shift away from conditionality on privatization and $\mathrm{SOE}$ restructuring was more pronounced than that of the IMF (World Bank, 2005). Fund arrangements often included detailed PC and PA in areas of core World Bank competency while the Bank imposed only vague or no conditions at all. At the same time, both organizations increased their involvement in the financial sector and in basic fiduciary issues. Given the abovementioned lack of roadmaps in program documentation, it is difficult to judge whether these developments reflect serious problems in Bank-Fund cooperation or better prioritization of structural reforms by both institutions. In any case, these developments run contrary to the expectation that the Bank would lead the work in non-macro core areas, while the Fund would reduce its involvement. This finding raises questions on how the Fund should address critical reforms in IMF noncore areas, particularly when the World Bank is not addressing them.

45. The evaluation findings are not fully consistent with the aims of the CG, since (i) the number of structural conditions did not diminish; and (ii) arrangements continued to include conditions that do not appear to have been "critical to the program objectives," while some critical issues, particularly in non-core areas, may have been ignored.

46. Several factors contributed to the lack of progress in reducing the number of conditions. A review of directors' discussions on arrangements submitted to the IMF Board during 2003-04, as well as the discussions during country programs and the bi-annual reviews of conditionality, shows that the lack of progress was not of great concern to the Board or to management. ${ }^{14}$ In specific country programs, objections to excessive conditionality by some executive directors were offset by the interest of other direc-

${ }^{14}$ The sample includes all programs requested in 2004 and some requested in 2003 - split in half between SBAs and PRGFs. The overall group includes Argentina (SBA, 2003), Bangladesh (PRGF, 2003), Bolivia (SBA, 2003), Ghana (PRGF, 2003), Kenya (PRGF, 2003), Nepal (PRGF, 2003), Paraguay (SBA, 2003), Macedonia (FYR) (SBA, 2003), Gabon (SBA, 2004), Bulgaria (SBA, 2004), Croatia (SBA, 2004), Peru (SBA, 2004), Romania (SBA, 2004), Ukraine (SBA, 2004), Burundi (PRGF, 2004), Georgia (PRGF, 2004), Honduras (PRGF, 2004), Mozambique (PRGF, 2004), Republic of Congo (PRGF, 2004), Zambia (PRGF, 2004), and Mali (PRGF, 2004). tors, usually from donor countries, in the role that these conditions could play in monitoring their own initiatives. Generally, directors calling for more conditions had a much stronger interest in the programs in question. ${ }^{15} \mathrm{~A}$ similar example relates to the support by many EU members for multiple and wide-ranging conditions in arrangements with countries that are in the EU accession process. In a few cases, the authorities themselves asked to add conditions that they expected would help them signal to donors a change in their commitments to specific reforms. Moreover, during the 2005 review of the $\mathrm{CG}$, directors noted that the number of conditions had not been reduced, but they agreed that numbers were "at best a crude metric."

47. The Executive Board, management, and staff have argued that the shift of conditionality toward the core areas is consistent with the implementation of the CG. But views differ on whether programs have sufficiently addressed criticality. In particular, Board signals have been mixed, with some directors arguing that there is scope for further streamlining, and others expressing regret that streamlining conditionality might have gone too far and calling for greater coverage of growth- and efficiency-related reforms.

48. The staff survey conducted for this evaluation found widely differing views among staff on what the CG require in terms of focus (and numbers) of structural conditions, and on how the criticality test is being interpreted. About two-thirds of the staff surveyed believed that being within a core area of Fund expertise was a necessary condition for a measure to be subject to conditionality; while about 20 percent thought that the measure needed to be critical for the achievement of the program's stated objectives independently of whether it was in the core. Notably, a majority of survey respondents felt that the streamlining initiative had weakened some programs, and about half believed that critical non-core conditions were being left out either "often" or "very often." During focus group discussions, staff noted that in designing conditionality they paid close attention to the CG, as well as to executive directors' past reactions to conditionality and program design - but that these had not provided clear guidance on the issue of criticality.

\footnotetext{
${ }^{15}$ About half of directors' interventions did not call for either more or less structural conditionality, and several indicated satisfaction with the proposed volume of structural conditionality. Of the remainder, those calling for more structural conditionality outnumbered those calling for less by a wide margin. In some cases, directors acknowledged that the number of conditions was very large but accepted it nonetheless, due to country-specific circumstances - particularly in EU accession countries and countries with poor past records of implementation. This finding is in line with staff responses to a survey, where one-third noted that directors had raised concerns about insufficient structural conditionality. In contrast, only 6 percent indicated that directors had expressed reservations about excessive conditionality.
} 
49. The Fund's internal review process ${ }^{16}$ emphasized the need to strengthen critical reform policies in IMF core and non-core areas alike. Sometimes reviewers called for additional conditionality, but they very seldom suggested dropping other specific conditions. The review process pointed out weaknesses in program documentation, sometimes requesting greater clarity of program objectives and of the strategies to achieve them, and calling for a longer-term outlook in the design of PRGF. But the review process had little impact on the quality of program documentation; for the ten PRGFs

${ }^{16}$ The internal review is conducted by staff in departments other than the corresponding area department. The analysis of the internal review was based on documents for ten arrangements approved in 2004. approved in 2004-05 that were examined for this part of the evaluation, most of the documents had objectives that were too broadly stated, weak explanations of the intermediate strategies to reach them, and no thorough explanation of why certain conditions were included. One important cause for these shortcomings was raised by the reviews themselves - programs appeared to be rushed and premature. Sometimes the rush may have only affected the quality of the documentation, but in other instances it may have also hindered the program design and its effectiveness, particularly in countries with a weak track record in reform. The rushed timetable was often set by exogenous processes, e.g., meeting deadlines for the HIPC process, while in other instances it was determined by an attempt to support a reformist group within the government. 


\section{5 5}

\section{Main Findings and Recommendations}

\section{Main Findings and Conclusions}

50. The following are the main findings and conclusions of the evaluation, which motivate its recommendations.

1) The number of structural conditions in Fund programs remained stable at about 17 per program-year, contrary to expectations when the streamlining initiative was launched. This was so, in part, because of a strong demand by donors and others to include SC in Fund arrangements as a monitoring tool for their own programs and initiatives, such as for HIPC or the EU accession process. Also, in some cases, members of the economic team requested specific conditionality to help them leverage their domestic policy goals.

2) The bulk of structural conditions had only limited structural depth: more than 40 percent of them called for preparing plans or drafting legislation and about half called for one-off easily reversible changes. Fewer than 5 percent required actual changes in legislation or other durable structural changes, and within this group fewer than one-third were complied with.

3) In spite of these factors, the large number of conditions was widely criticized as intruding in the policymaking process and detracting from society's sense of ownership of programs. Resistance to and stigma linked to IMF conditionality reflect in part the public's lack of knowledge and understanding about the different sources and types of conditions.

4) Only about half of the structural conditions were complied with on time. Moreover, there was only a weak link between compliance with SC in a Fund program and subsequent additional reforms in the corresponding sector-a weak measure of the effectiveness of conditions in bringing about reform.
5) Ownership of the reform program by a strong economic policymaking team is critical for the implementation of conditionality. But to sustain the reforms at the country and the sectoral levels, broader government ownership-at least ownership of the specific conditionality by the corresponding implementing bodiesseems to be a precondition.

6) Both compliance and effectiveness differed across sectors; they tended to be higher in the areas of core competency of the IMF, such as PEM and tax administration, and lower in non-core areas, such as privatization and reform of the wider public sector.

7) After the streamlining initiative was launched, the composition of SC shifted significantly toward IMF core areas, e.g., PEM and tax administration, as well as to new areas of basic fiduciary reforms, e.g., financial management and controls, which became important for donors trying to move their aid away from project-based to general budget support. At the same time, the IMF moved away from controversial areas where it had little impact and that largely fell within the World Bank's core competency.

8) There is a lack of clarity on whether the shift was fully consistent with the "criticality" requirement set by the CG. Many of the conditions do not appear to have been critical to the program objectives, while some policies that were not covered by conditionality may have been critical.

9) World Bank conditionality has moved away from issues such as privatization and restructuring of SOE that are considered part of the Bank's core competency. The simultaneous shift by both organizations raises questions as to whether some critical reforms were not addressed. 
10) Progress has been uneven in ensuring that program documents are clear about criticality, i.e., about how specific structural conditions would support program objectives. Moreover, in most PRGFs the program documentation does not specify a roadmap for the intended reforms.

\section{Main Recommendations}

51. Policy review. The Board should clarify what it expects in terms of numbers and focus of structural conditions. The findings of the evaluation suggest that the Board would be well advised to reaffirm the need to use SC sparingly and only when it is critical for achieving program objectives or safeguarding IMF resources. As a first practical step, the Board could consider setting a notional cap on the number of structural conditions per program-year. Initially, the cap could be set at about one half of the current average of PCs and PAs, or some four to five conditions per year. This mechanistic constraint would force all parties (e.g., Board, management, and staff) to justify the "criticality" of each condition. To help implement this recommendation, the Board would need to clarify whether and how SC in IMF arrangements should continue to be used as a monitoring tool for donor-led programs and other initiatives. To address the demand for SC for these purposes, the Fund should consider greater use of non-lending instruments such as more frequent surveillance, and other existing or new monitoring tools.

52. Program and conditionality design. Staff should work with country authorities to identify clearly the main goals of each program and to set structural conditions that contribute significantly to these goals. Fewer prior actions and performance criteria should be used, and they should focus on reforms that are expected to have a significant and sustainable impact. To ensure their relevance and proper design, as well as to enhance their effectiveness, the conditions set should pertain to the core areas of IMF responsibility where staff has in-depth knowledge: fiscal and monetary policy, and certain aspects of finance and trade. The use of structural benchmarks should be discontinued, and conditions with low structural content should not be part of conditionality. Generally, the Fund should accommodate national authorities' desire to have program-related documents address policies that are not subject to conditionality. But these documents should clearly distinguish between the conditions on which IMF financial support depends and other elements of the authorities' policy agenda.
53. Cooperation with the World Bank. The sustainability of structural reforms and macroeconomic adjustments often depends on changes in a country's wider public sector and on restructuring of quasifiscal expenditures. In setting SC in these areas, however, the IMF should play a subsidiary role to that of the World Bank, which has primary responsibility and greater expertise in these areas. The management of both organizations should consider means to help country authorities to diagnose constraints and prepare homegrown strategies for reform. Explicit Board guidance would still be needed in instances in which policy changes in non-core areas are deemed critical but effective cooperation with the Bank is unlikely to crystallize in time.

54. Development of a monitoring and evaluation framework. The assessment of whether SC in Fund arrangements was effective is complicated by the lack of an agreed framework to assess results and accountability, and the consequent lack of some of the necessary information. The Fund should develop a monitoring and evaluation framework linking conditions in each program to reforms and specified goals. This would provide a more robust basis for monitoring the implementation and evaluation of programs, as well as facilitating learning on what works and what does not. Such a framework would allow staff to better define what data need to be collected before, during, and after a program. As an interim measure, the staff needs to improve the system used to track conditionality (MONA), with a view to disclosing these data and thus facilitating accountability as well as learning by authorities in member countries.

55. Information in Board documents. Program documentation needs to be more explicit about the objectives being supported by the IMF and how the measures being proposed would help achieve these objectives. For PRGFs, in particular, program requests should be accompanied by an operational roadmap covering the length of the program, elaborating on the modalities of the reforms and on their sequencing and expected impact.

56. IMF outreach. Outside criticism of Fund conditionality and resistance to requesting IMF support for stabilization and economic reform programs may stem in part from misunderstandings about how structural conditions are set and by whom. While implementation of the recommendations above would likely improve the situation, the IMF would need a greater outreach effort to clarify these issues. To be effective, such an effort would need to be supported by the Executive Board and the member countries. 


\section{References}

Abdilina and Jaramillo-Vallejo, 2005, "Streamlining Structural Conditionality in World Bank- and International Monetary Fund-supported Programs," in Stefan Koeberle and others (eds.), Conditionality Reviewed, Washington, DC: World Bank.

Action Aid, 2004, "Money Talks: How Aid Conditions Continue to Drive Utility Privatisation in Poor Countries," United Kingdom.

Eurodad, 2006, "World Bank and IMF Conditionality: A Development Injustice,” Eurodad Report (June).

Independent Evaluation Office (IEO), International Monetary Fund, 2004, Report on the Evaluation of Poverty Reduction Strategy Papers and the Poverty Reduction and Growth Facility. Washington, DC: IEO.

IMF, 2005a, Review of the 2002 Conditionality Guidelines," SM/05/81, (March). Washington, DC.

,$- 2005 \mathrm{~b}$, Review of the 2002 Conditionality Guidelines-Selected Issues, SM/05/82, (March).

, 2002, Guidelines on Conditionality. Washington, DC: IMF. Available at http:// www.imf.org/External/
np/pdr/cond/2002/eng/guid/092302.pdf+IMF+ conditionality+guidelines $\& \mathrm{hl}=\mathrm{en} \& \mathrm{ct}=\mathrm{clnk} \& \mathrm{~cd}=1$

, 2000, "Interim Guidance Note on Streamlining Structural Conditionality." Available at imf.org/ external/np/pdr/cond/2001/eng/collab/071001.pdf

Jubilee Debt Campaign, 2006, "Tightening the Chains or Cutting the Strings? The Status of HIPC Conditionality in 2006."

Oxfam International, 2004, "From 'Donorship to Ownership?' Moving Towards PRSP Round Two,” Oxfam Briefing Paper 51 (January).

Wood, Angela, and Matthew Lockwood, 1999, "The 'Perestroika of Aid'? New Perspectives on Conditionality," Bretton Woods Project, Washington, DC. Available at www.brettonwoodsproject.org/topic/governnance/ poa2.pdf

World Bank, 2005, "Recent Trends and Practices," Background Paper No. 3 in Review of World Bank Conditionality, September. Washington, DC: World Bank. 
This page intentionally left blank 


\section{Statement by the Managing Director IMF Staff Response}

\section{IEO Comments on Management and IMF Staff Responses}

The Chair's Summing Up 
This page intentionally left blank 


\title{
Statement by the Managing Director on the Evaluation by the Independent Evaluation Office on Structural Conditionality in IMF-Supported Programs
}

\author{
Executive Board Meeting \\ December 12, 2007
}

Management welcomes the Independent Evaluation Office (IEO) report on Structural Conditionality in IMF-supported programs, which provides a wealth of useful information and echoes many of the findings of the staff's own analysis in the 2005 Conditionality Review. The IEO report has already been helpful in disseminating lessons for program design in the Fund and has triggered a stimulating discussion among departments on the subject of conditionality. In this regard, it has already served to enhance the Fund's learning culture.

It is important to recall that the streamlining initiative was intended to foster country ownership by bringing about a change in the Fund's mindset about program design; namely, from comprehensiveness to parsimony, thus serving to focus programs in key areas. The initiative, which culminated in a comprehensive revision of the Conditionality Guidelines in 2002, concluded that conditionality should be limited to measures that are: (i) critical to achieving program goals, (ii) critical to monitoring the implementation of a program, and (iii) necessary to implement specific provisions of the Articles or policies adopted under them. In particular, conditionality that is not critical for these purposes, however economically beneficial it may be, should not be established.

Moreover, as the Executive Board has stressed in many occasions, the "number of conditions is at best a crude metric", and more important than the number of conditions is "their quality and mutual consistency". In this regard, the primary aim is to tailor conditionality to program goals, recognizing that it is not uncommon for a single substantive reform to involve numerous steps and, as a result, it is more likely to include a number of conditions.

The IEO report provides evidence of considerable success in implementing the Conditionality Guidelines:

- There is evidence of a shift from comprehensiveness to parsimony in the coverage of con- ditionality; in particular, fewer areas of reform are targeted, suggesting greater focus in the design of recent Fund-supported programs.

- In the IEO's own words, the streamlining initiative has "helped to shift the composition of conditionality towards Fund core areas," which are more likely to be critical to achieving the goals of the programs that the Fund is supporting.

- This change in mindset is also reflected in the IEO's finding that conditionality in some sectors has declined (for instance, in trade-related and public enterprise reforms-where the reform measures, though otherwise beneficial, may be less critical to achieving the goals of the Fund-supported program).

- While the IEO would prefer to see a greater reduction in numbers, it is worth noting that in their own view the vast majority (95 percent) of conditions do not require deep structural reforms. As such, they should not be onerous or unduly burden national authorities' implementation capacity.

- The IEO finds no evidence that programs with more conditions had lower rates of implementation; on the contrary, as one example, program delays were fewer.

The IEO states that Fund arrangements included conditions that seem not to have been critical to program goals. On this point, however, the report provides little specific evidence — and disregards the other important purposes of conditionality noted above. The IEO's view seems to be based on its "structural depth" indicator but, as noted in the staff response, limited depth does not necessarily imply that the measure was not critical for the Fund-supported program goals or the other purposes of conditionality.

The report suggests that structural conditionality has been ineffective because in 45 percent of cases it did not spur further reforms. Under the Conditionality Guidelines, however, conditionality is supposed to 
underpin measures critical to the program's success, monitor program implementation, and facilitate implementation of the Articles-not to initiate reforms beyond the program period except, of course, for ensuring that external viability can be sustained. The IEO's view mixes the provision of policy advice with conditionality during a program, and could be viewed as intruding in national policy making and thereby undermining country ownership.

Finally, the IEO report argues that the Fund should play a subsidiary role in non-core areas of its expertise. However, the Fund must be responsible for its lending decisions and must ensure that the programs it supports can be successful. To do this, the Conditionality Guidelines require that conditionality cover all measures critical to achieving program goals-regardless of whether they are in core or non-core areas. Of course, in non-core areas, Fund staff should continue to draw on the expertise of other institutions.
We also agree with the report's suggestion that the link between program goals, strategies and conditions could be better explained and articulated in Board papers - and this should be monitored. We further agree with the report's emphasis on greater outreach. Fund outreach activities should aim at explaining the purpose of conditionality; indeed, it is important that our members, civil society, and other stakeholders understand both how much has already been achieved and what challenges remain ahead.

In conclusion, we welcome the IEO report and look forward to the Board discussion, which will provide the opportunity to draw out further the implications for the Fund's policies and procedures and for program design. The accompanying staff comments provides further details on our response to the Report's findings and recommendations. An implementation plan of Board-endorsed recommendations will be presented to the Board in early 2008. 
IMF Staff Response to the Evaluation by the INDEPENDENT EVAluAtion

Office on Structural Conditionality in IMF-Supported Programs

\author{
Executive Board Meeting \\ December 12, 2007
}

\title{
Summary of Comments
}

- Key findings of the report echo those of the 2005 Conditionality Review. In this regard, some of the conclusions reached at the time are worth restating (PIN No. 05/52).

- Directors agreed that: (i) "numbers of conditions are at best a crude metric", (ii) "it is appropriate for conditionality to cover all critical measures", and (iii) "even more important than the numbers ofz conditions are the quality and mutual consistency."

- Directors welcomed "the streamlining of the breadth of coverage of conditionality, in line with the requirement that such conditions be deemed 'critical' to the goals of Fund-supported programs" and "that conditionality has shifted away from non-core areas."

- They were pleased "that the sectoral coverage of the Fund's conditionality now appears largely unaffected by the presence or absence of a Bank-supported program."

- Against this background, the differences between the IEO and staff on how to interpret the IEO findings stem from a different view about the purpose of conditionality. In staff's view

- Streamlining was intended to bring about a change in the Fund's mindset about program design-from comprehensive- ness to parsimony, thus serving to focus programs in key areas.

- Criticality cannot be defined mechanistically and must be judged case-by-case. For example, it is not uncommon for a single substantive reform to involve numerous steps and, as a result, it is more likely to include a number of conditions.

- While effectiveness of conditionality is difficult to measure, staff has doubts that the metric should relate to furthering reforms beyond the scope of the Fund-supported program except of course for ensuring that program goals can be sustained over the medium-term. A more useful metric is whether program goals — narrowly defined-were achieved and sustained.

- Staff do not agree with the report's implication that the World Bank should necessarily be involved in sectors that the Fund is not covering, nor the related recommendation that the Fund should play a "subsidiary role" in noncore areas of reform.

- Staff agree that the link between program goals and strategies-and the explanation of program conditionality-could be better documented in staff reports.

- There is also a need to undertake outreach that would expand the understanding of civil society and other stakeholders regarding the purpose and confines of Fund conditionality. 
1. The IEO's report contains a wealth of information and is a valuable complement to the staff's own conditionality review $(\mathbf{C R}, \mathbf{2 0 0 5})$. Many of the quantitative findings in the IEO report echo those highlighted in the CR. Given the controversial nature of conditionality, the IEO can bring the credibility of its independence to bear on this subject, which is key for improving program design. As with any evaluation, it is important to identify what can be learned for the future, while acknowledging the limitations of the analysis and the need to provide an assessment that is informed by the governing Board-established conditionality framework.

\section{Comments on the Evaluation}

2. While staff concur with many of the IEO's findings, differences on how to interpret the evidence stem from a different view about the purpose of conditionality. In staff's view, as embodied in the Conditionality Guidelines (CG), conditionality is intended to assist members to solve their balance of payments problems by focusing on measures that are critical to achieving the goals of the member's program and monitoring their implementation, interrupting Fund support when program goals are unlikely to be achieved. In effect, conditionality provides the member with predictability regarding the availability of Fund lending while safeguarding the revolving nature of the Fund's financial resources. The Conditionality Guidelines also call for conditionality to be established where necessary for the implementation of specific provisions of the Articles of Agreement or the polices adopted under them. In contrast, the IEO takes the view that conditionality should foster further reforms in individual areas beyond the program's goals and beyond the program period-this, in staff's view, would seem to imply considerable intrusiveness on national policy making and be contrary to the spirit of the CG and the streamlining initiative.

3. Moreover, the streamlining initiative was notand should not bea-numbers game."

First, as implicitly recognized in the IEO report, the number of conditions says little about the intensity or ambitiousness of reforms, and the number of individual steps (and therefore conditions) that correspond to one substantive economic action is likely to differ across programs to take account of the nature of this reform, including the authorities' preferences and technical capacity. Second, as the IEO report indicates, the content of structural measures differs widely, as does their likely difficulty in implementation, so the aggregate number of conditions is not a good measure of burden. Third, while there may have been some expectation that the average number of conditions would decline, the main concern was that a few programs had a very large number of conditions that overwhelmed implementation capacity and that programs covered too many different reform areas. As one example, the 5 largest programs prior to the streamlining initiative had 10 more conditions per program year than is the case for the 2001-05 period. ${ }^{1}$ Finally, since the aim is to tailor conditionality to the program objectives being supported, it must be recognized that it is not uncommon for a single substantive reform to involve numerous steps. In such cases this reform is likely to include a large number of structural conditions.

4. In sum, streamlining was intended to bring about a change in the Fund's mindset about program design. ${ }^{2}$ Prior to the $\mathrm{CG}$, there was a tendency to incorporate measures that were considered economically beneficial to the country-even if not necessary for achieving the goals of the program. In this regard, streamlining was intended to shift program design from comprehensiveness to parsimony in the application of conditionality. More precisely, Fund conditionality would be limited to measures considered critical to achieving and monitoring the program's goals while ensuring that medium-term external viability is sustained. National authorities may, of course, implement other reforms but-regardless of how beneficial they may be-these should not be subject to Fund conditionality. ${ }^{3}$

5. Evidence that such a shift has occurred is provided in the IEO report (BP, II29- $\mid[35)$. For instance, there is a downward shift in the relationship between the number of trade-related conditions and trade restrictiveness between programs approved in 1995-2000 and programs approved in 2001-04 (BP, Figure 2.6). As the IEO report notes "the fall in the number of trade-related conditions was not driven by a reduction in trade restrictiveness, but by the Fund's own initiative to streamline its conditionality." This is precisely the purpose of the streamlining initiative: to the extent that trade reforms are not critical to achieving the program goals, they should not be subject to Fund conditionality-regardless of their own merits and regardless of the degree of structural distortions involved. The same

${ }^{1}$ As noted in CR (2005), Executive Directors stressed during the 2000-02 conditionality review that the number of conditions is only one, imperfect, indicator of the extent of progress with streamlining.

${ }^{2}$ See Summing up of the 2001 Executive Board discussion of Conditionality in Fund-supported Programs, which states "While these principles would need to be interpreted on case-by-case basis, they would shift the presumption of coverage from one of comprehensiveness to one of parsimony."

${ }^{3}$ Moreover, both the Interim Guidance Note and the Conditionality Guidelines emphasize that in such cases there should be clear delineation between the authorities' broader reform agenda and measures that are part of the Fund-supported program and subject to Fund conditionality. 
appears true in other areas, such as privatizationrelated conditionality (BP, Figure 2.7). In sum, whereas such conditions were often included in the Fund arrangements, the IEO report suggests that this practice has diminished.

6. In addition, criticality cannot be defined mechanistically and must be judged on a case-bycase basis, as highlighted in the country-specific comments (Appendix 1). The IEO report ( $(145)$ contends that "arrangements continued to include conditions that do not appear to have been critical to the program objectives" while "some critical issues, particularly in non-core areas, may have been ignored."

- On the former, the report does not provide concrete evidence beyond the structural depth indicator. But the IEO's concept of structural depth (SD) does not mesh with the purpose of conditionality. Structural benchmarks, for example, will often be "limited or no" SD measures under the IEO's definition, as they are intended to signify critical mile posts in the process of program implementation (in the words of the $\mathrm{CG}$, "to serve as clear markers in the assessment of progress in the implementation of critical structural reforms in the context of a program review" (see CG I[11(d)(ii)). Also, the structural depth indicator does not correctly appreciate how programs are tailored to country-specific circumstances-in this regard, flexibility on how measures are defined is key to program success (e.g., the use of small steps has been found to work best in some countries). ${ }^{4}$ Thus, the Board-established framework governing program design expressly contemplates that conditions may appropriately have what the report considers to be of "limited or no" SD. 5

- Moreover, the shift towards core areas suggests that measures subject to conditionality are indeed more likely to be critical than was previously the case. This is reinforced by the IEO's analysis of permanent program interruptions (which have declined, especially for GRA-supported programs)

\footnotetext{
${ }^{4}$ For example, the performance criterion on the issuance of a tender for the privatization of SONACOS in Senegal was a key step toward divestiture and, while the process was not without delays, a privatization with key macro implications was ultimately achieved. In other countries a similar measure might be set on actual divestiture. While in both cases the measure is in the end met, only the latter would be assigned a high SD rating in the IEO's view.

${ }^{5}$ Inasmuch as high SD measures are likely to be more onerous to implement (the IEO finds that their implementation rate has indeed be lower), this suggests that program design has sought parsimony. This is consistent with the $\mathrm{CG}$, which require that conditions be set so that program goals will be achieved while tailoring these to the member's own political considerations and technical capacity.
}

and the staff's analysis of waivers, which shows that the "lapsed rate"6 (i.e., the proportion of all SPC that were waived and the program allowed to continue without the measure or an equivalent measure being implemented; see CR) has declined-as would be expected if measures subject to conditionality are indeed critical. ${ }^{7}$

- On critical issues being ignored, the report does not distinguish between measures that may be important (or even critical) for the authorities' broader reform agenda and those that are critical for achieving the goals of a program. As noted above, only the latter should be subject to Fund conditionality. Accordingly, a Fund arrangement would typically be viewed as supporting only a subset of the authorities' broader reform agenda.

7. Since one of the purposes of conditionality is to interrupt IMF support when goals are unlikely to be achieved, the IEO's measure of effectiveness appears to be too narrow. ${ }^{8}$ While reforms should not be reversed, the findings in the report suggest this occurs only in a small minority of cases ( 8 percent for core areas and 13 percent for non-core) - and in some 50-60 percent of cases there were further reforms. Staff does not consider that conditionality should be judged ineffective if the country does not undertake further reforms in the area since:

- Under the CG, conditionality is supposed to underpin measures critical to the program's success-not to initiate reforms beyond the program. ${ }^{9}$

- Program measures may have addressed the most important structural reforms in that sector (e.g., if prices are liberalized, there should be no need to do so again).

- Even though a measure may have "low structural depth" (as defined by the IEO report) this does not imply that it is not critical to program success. The example provided in the IEO report ( $(16$, footnote 5$)$ is a case in point: passage

\footnotetext{
${ }^{6}$ See CR (2005) 950 , Figure 11.

${ }^{7}$ The IEO methodology of examining ex post correlations-no significant correlation is found between compliance and effectiveness and between compliance and depth-might not adequately control for country-specific circumstances. For example, stronger conditionality may have been imposed on harder cases, in which case the lack of correlation could be construed as the Fund, ex ante, imposing the right balance of conditionality at the margin.

${ }^{8}$ In addition to practical and budgetary considerations, this is one of the reasons why the MONA database does not track conditionality once a program goes off-track and the arrangement expires (II8).

${ }^{9}$ One reason that the report finds that measures in core areas have been more effective is that the subsequent Article IV report may not have tracked further progress in non-core areas.
} 
of the annual budget is very likely to be critical in a program that aims at economic stability and external adjustment.

8. While effectiveness is difficult to measure, a more useful metric is whether conditionality helped achieve a program's macroeconomic goals. Staff's own analysis suggests that structural measures have helped underpin these goals. For example, fiscal structural measures (revenue-related measures) are statistically significantly related to fiscal adjustment, and economic efficiency-enhancing measures are statistically significantly related to growth performance. ${ }^{10}$ It would also have been useful to highlight the link of timely, targeted Fund technical assistance in the design and implementation of conditionality, given the report's finding of enhanced compliance with conditionality in areas where substantial TA resources are devoted.

9. Staff agree that the link between program goals and strategies, and the explanation of program conditionality, could be described better in Staff Reports supporting requests for the use of Fund resources. The IEO report notes that "the streamlining initiative did not lead to better explanations of why conditions, either core or non-core, were critical, nor of how these conditions would contribute to program objectives" (II43) and "sometimes the rush may have only affected the quality of the documentation, but in other instances it may have also hindered the program design and its effectiveness" (II49). While the CR was somewhat more sanguine, it too noted that "some room for improvement exists at least in the presentation, and possibly also in the formulation, of strategies."

10. The IEO's different view about the purpose of conditionality carries over to its views regarding coverage of conditionality between Bretton Woods institutions. In particular, there is no reason why the World Bank should necessarily include (or increase) its conditionality in reform areas no longer covered by Fund conditionality (II44). The CG require that the Fund include conditionality on measures critical to achieving the goals of the Fundsupported program regardless of whether these lie within or outside the Fund's core areas. In non-core areas, the CG envisage the Fund drawing on the expertise of other institutions (e.g., the Bank) in the design of its conditionality and its monitoring-hence the "lead agency" concept, whereby one of the two institutions would take the lead in providing substantive policy advice. However, the IEO report does not distinguish between the provision of policy advicewhich should be responsibility of the institution with greatest expertise in that area-with conditional-

\footnotetext{
${ }^{10}$ See The Design of IMF-supported Programs (OP 241, pp. 146-147).
}

ity, where each institution is responsible for its own lending decisions and must therefore include conditionality if the measure is critical to the program it is supporting. 11,12

\section{Comments on IEO Recommendations}

11. While many of the IEO's findings are consistent with strong implementation of the CG, some do point to areas in need of improvement. Nonetheless, some of the IEO report recommendations do not adequately take into account of the purpose of conditionality and the difference between program design and the provision of policy advice more generally.

12. In this context, staff agree that program documents could do a better job; in particular laying out program goals, how proposed strategies would contribute to achieving these goals, and the conditionality that may be used to monitor that the proposed strategies are in place. Further clarifications in guidance notes on the application of the $\mathrm{CG}$ might be useful, including a reaffirmation of the need to use conditionality sparingly and only when critical to achieving program objectives (and program monitoring), or where necessary for the implementation of specific provisions of the Articles of Agreement or policies defined under them.

13. The proposed notional cap has risks and might not accomplish greater clarity. Such cap could prove rigid and constrain program design, as well as open the Fund to a "one-size-fits-all" criticism. Moreover, the IEO report provides no evidence that a larger number of structural conditions was associated with weaker implementation; if anything, the evidence suggests that it had a positive effect in reducing program delays (BP, Figure 2.11) and did not result in lower implementation rates (II21). Notwithstanding the above, a notional cap or guideline-if applied flexibly and with due regard to special circumstances-could on occasion help increase

${ }^{11}$ As CR $(2005$, II68) notes, "it is not obvious that gaps in BankFund conditionality need to be viewed with concern. Much more worrisome would be gaps in analytical work, policy advice or technical assistance"-Bank-Fund collaboration on these areas was considered in the Malan Report and is taken up in this report's implementation plan.

${ }^{12}$ An example could be the privatization of a telecom company. Such privatization (within fixed timetables and short horizons) may be critical to the Fund-supported program because of (i) the budget needs the privatization receipts or (ii) the enterprise is incurring large budgetary losses. In contrast, for a Bank operation-which may be concerned with an overall restructuring the telecommunications sector-the privatization by a fixed timetable is less likely to be critical. Notwithstanding this distinction, Fund staff would want to draw on the Bank's expertise-for instance, on whether the sale makes sense from the overall strategy for the sector and what would be a feasible timetable. 
program focus. As to new non-lending instruments, staff's view is that policy support instruments (PSI) provide the needed monitoring tool where donor-led programs have a central role and believes that bilateral surveillance remains the best mechanism for the provision of policy advice outside a Fund-supported program.

14. Staff do not think that eliminating structural benchmarks would be appropriate; nor, for that matter, eliminating measures with low structural depth. Benchmarks play many roles (from mile posts in broader reform areas, to the direction of reform in critical areas where it is not possible ex ante to specify the required measures with the precision) required for a performance criteria. In particular, they help define the contours of program reviews and thereby provide the link between progress with the reform agenda and assurances about the availability of Fund financing. Their elimination would weaken the assurances aspect of conditionality and revive the criticism of moving reform goalposts. That said, it could be useful to reiterate in guidance notes that benchmarks should be limited to areas of reform that are critical to achieving program goals. As noted earlier, what might be viewed as low structural depth is, on occasion, key step toward the success of the Fund-supported program.

15. Staff do not agree with the report's implication that the World Bank should be involved in sectors that the Fund is not covering, nor its recommendation that the Fund should play a subsidiary role in non-core areas of reform. The CG require the IMF to have conditionality on those measures critical to the program it is supporting; and, not surprisingly, the World Bank has similar fiduciary responsibilities. Again, the report seems to confuse provision of policy advice with the need for conditionality. Of course staff is expected to draw on the expertise of other institutions (notably, the World Bank or other MDBs) in non-core areas for policy advice and the design of conditionality. Moreover, initiatives (e.g., JMAP) underway lay out processes for initiating and coordinating work where the Bank has clear lead responsibility and greater expertise and for better coordination in joint areas. Still, the Fund's own fiduciary responsibilities - confirmed by the Board in many occasions and clearly specified in the $\mathrm{CG}$-would require setting conditionality in all areas critical for program success.

16. The report calls for "explicit Board guidance" for cases where reforms in non-core areas are critical to program goals but the Bank is unable to deliver (II57). However, this seems a non sequitur since the report separately recommends that all conditions in Fund arrangements "should pertain to the core areas of IMF responsibility" (II56). The latter implies that conditions should never be set in non-core areas. Thus, by this logic, in cases requiring critical reforms in a non-core area where the Bank is unavailable the only option would be to refuse IMF financing.

17. Staff agree that a framework to monitor whether program documentation lays out goals, strategies, and justification for proposed conditionality would be helpful. This could be done at a higher frequency than the current 5-year cycle of conditionality reviews and could prove useful in informing program design. Staff does not consider that conditionality is primarily intended to foster further reforms than what is needed to achieve the program goals; thus, a monitoring framework linking conditions to specific outcomes would not be appropriate. Instead, conditionality reviews should focus on whether programs achieved their macroeconomic goals.

18. As to the availability of MONA, much of it is already made available to researchers and civil society upon request. For instance, for previous programs and original program requests for current arrangements, the dataset is made available when the information is in the public domain (i.e., the staff report is published, which is the presumption for requests for use of Fund resources). To provide information on real-time basis would be very resource-intensive, but what is currently provided to researchers upon request could be routinely posted on the web.

19. Staff agree that the Fund needs to improve its outreach activities. In fact, the report provides evidence that the vast majority of structural conditions in Fund-supported programs should not be very burdensome to implement, "yet the large number of conditions was widely perceived as intruding in the policymaking process and deterring from society's sense of ownership." The resistance and stigma are partly linked to the public's lack of knowledge about the sources and types of conditions. Likewise, the literature review (BP, Chapter I) suggests a lack of understanding about the purpose of IMF conditionality and how it is intended to work.

\section{Appendix I. Specific Comments and Factual Corrections}

\section{General Comments}

It is not clear if the programs covered by the "desk studies" (the 43 programs approved in 1999-2003) are all under the streamlining initiative. It would be useful to include a list of programs covered under each of the analytical methods used, including the programs reviewed for 2004-05. 
The claim that AFR did not request follow-up TA from FAD (Table 4.13.3) is inaccurate, as FAD delivered intensive TA since 2004 at AFR's request including a PFM TA mission (July 2005); tax and custom administration TA mission (March 2006); peripatetic visits in tax administration (January, May and September 2007) and in customs administration (January, May and September 2007); and tax policy TA missions (February, July and September 2007).

\section{Country-Specific Comments}

In staff's view the conclusions drawn from the case studies suffer from an overly mechanistic approach to structural conditionality and could have been better balanced if they had considered the broader picture of the environment in which country programs were designed. The comments below highlight the importance of factors other than program design to the ultimate "success" of a program; for instance, in Madagascar, where civil strife impeded progress under the program; and Ghana, where ownership of the new program by the authorities was a key success factor.

\section{Cameroon}

- Page 54, Table 4.2: Many of the reforms mentioned have laid the ground for subsequent substantial improvements (in particular in PFM), even though they are judged to have only limited short-term effects. Moreover, some of the short-term achievements of the program are not fully reflected in the analysis in Table 4.2. For example, the absence of a crisis in the financial system should be viewed as a success taking into account the circumstances at the time. Specifically, the issue of saisie-attribution was a problem threatening the viability of banks and the program took actions to stop this practice.

- Page 87, Table 4.9.4: (i) The report suggests that earlier emphasis on tax administration would have helped, however efforts before the 2000 PRGF had focused on tax policy (i.e., the VAT). The assessment on customs is overly critical-through conditionality and critical TA from the World Bank, the 2000 PRGF managed to kick start the previously stalled reform momentum and deliver critical measures (such as the securitization of PAGODE, the customs IT system). (ii) The assessment should note that a lot of donors are involved in PEM reforms with mixed results. For example, significant delays materialized in the reform of the budget classification, because recommendations by an EU consultant ran contrary to best practices and FAD recommendations. (iii) Considerable progress has been achieved on public procurement since the end of the program, although further improvements are still required. (iv) On governance, the audit office has become operational but has been slow in auditing government accounts. (v) On HIPC, the low use of HIPC resources stemmed from the establishment of a donor committee, an idea that was imposed on the program by donors.

\section{Ghana}

- Page 17, I29: The report claims that the PRGF of 1999-02 achieved "little or no progress". While not contesting this conclusion, staff would point out that lack of progress was mainly due to weak institutional capacity/political commitment in the context of election-related fiscal profligacy. A striking phenomenon in Ghana's case is that with a change in administration, performance under the subsequent PRGF program ending in 2006 was successful. While Fund SC was unchanged under the second PRGF, what did change was the authorities' commitment to reforms. This highlights that in the end, Fund programs will be successful only if the authorities have full ownership.

Kenya

- Page 17, I29: The judgment that the Kenyan program achieved little or no progress should be placed in context. The reported lack of progress is consistent with the fact that no reviews were completed under the PRGF arrangement that was approved in 2000. For example, in Table 4.11.3 (page 97), the observation that there was "no substantial progress in PEM despite the authorities' high compliance rate" is misleading because the measures implemented were only initial steps in a long reform process. Had the program remained on track, one would have expected to see further milestones met. In a similar vein, in Table 4.11.4, the prospects for successful financial sector reform would have been improved had the program stayed on track with reviews completed.

- Pages 97-98, Tables 4.11.3 and 4.11.4: There is an unresolved tension between the discussion of financial sector reforms (output assessment) and of anti-corruption legislation and institutions (usefulness). In the former, the report argues that lack of progress stemmed from requiring only that legislation be submitted to rather than approved by parliament. Conversely, in the latter area, the report argues that conditionality 
requiring submission of legislation "provides an example of how structural conditionality can actually stigmatize desirable measures."

\section{Lao P.D.R}

- Tables 4.12.1, 4.12.3, and 4.12.4. It should be noted that the program was launched when Lao P.D.R. was coming out of a prolonged period of weak policies and macroeconomic instability. In this context, the authorities and the staff agreed that the initial stages of the program had to be focused primarily on securing macro stability. Conditionality aimed to complement the stabilization efforts and build a foundation for a gradual transition to a market-based system, while allowing the authorities time to build consensus on politically more difficult reforms. In this regard, the assessment on the implementation of structural reform seems unduly negative and excludes the authorities' recent reform efforts.

- Page 20, I[34. Staff strongly disagree that "collaboration [with the World Bank] was weaker in . . L Lao P.D.R," which staff believe is not a gen- eral consensus among the current and past Fund and Bank teams on Lao P.D.R.

\section{Madagascar}

- Page 17, I29: The qualification of Madagascar's program as having achieved little or no progress seems overly severe in view of the special circumstances under which the program was implemented (civil strife in 2002 causing output contraction by 13 percent).

- Page 103, Table 14.13.1: In staff's view the introduction of a continuous forex market was critical, even if bankers were against it because of the costs involved.

\section{Romania}

- Footnote 11: The report states that: "Fund arrangements provided a monitoring framework for the EU accession process, explicitly (e.g., Romania) or implicitly (e.g., Croatia)." There was, however, no explicit framework in Romania's accession process. 


\title{
IEO COMMENTS ON MANAgEMENT AND \\ StafF's REsponses to the Evaluation of \\ Structural Conditionality in IMF-Supported Programs
}

\author{
Executive Board Meeting \\ December I2, 2007
}

The IEO welcomes management and staff's concurrence with several of the evaluation's findings and recommendations, and is pleased to learn that the report has already been helpful in disseminating lessons for program design in the Fund and has triggered a stimulating discussion among departments on the subject of conditionality.

The IEO agrees that progress has been made on a key objective of the Streamlining Initiative and the 2002 Conditionality Guidelines, namely, to better focus programs in core areas. However, the call for parsimony extended beyond the issue of which areas should be subject to conditionality. The guidelines established that conditions would only be included if their implementation was critical to achieve program objectives. The Initiative and the Guidelines also generated the expectation, both within and outside the Fund, of a decline in the number of conditions (as acknowledged in the Review of the 2002 Conditionality Guidelines conducted in 2005).

Set against these expectations, the evaluation found that the concept of criticality included in the 2002 Conditionality Guidelines has not proven to be a sufficiently strong filter to bring about the desired results. There has not been a significant decline in the average number of conditions per program year since $2000 \mathrm{de}-$ spite the efforts to limit the areas covered. Also, conditions that were not critical continued to be included, e.g., SBAs approved in 2004 and 2005 included, respectively, conditions on the type of medical experts that could verify disability certification and on specific amendments to the Law of Misdemeanors (additional examples can be found in the case studies, including those in pages 62, 73, 107 and 117 of the Background Documents). It is against this backdrop that the IEO proposes a notional cap on the number of conditions to help further focus and reduce structural conditionality. Applied with some flexibility, the cap would force all stakeholders to prioritize and focus conditionality on critical reform, while leaving room to accommodate country-specific circumstances without making the Fund vulnerable to "one-size-fits-all" criticisms. Such a notional cap would also respond to the views expressed by some staff to the IEO that incentives in the current review system (and Board oversight) continue to favor comprehensiveness over parsimony so as to avoid a criticism that something has been missed.

While staff have suggested a lack of understanding of the purpose of conditionality, in fact, the evaluation did examine the role of structural conditionality in achieving program objectives and in providing members with predictability regarding the availability of Fund resources while safeguarding the revolving nature of these resources. The low compliance rate with conditions and their low degree of structural depth (defined as the degree of structural change that they would bring about if implemented) suggest that, during the period under review, structural conditionality did not, in general, play a critical role in meeting these goals. If programs were meeting their objectives, then it is hard to see how these unfulfilled conditions could have been critical, or what role they played in providing predictability. It is also unclear how low structural depth conditionality could play a role in safeguarding Fund resources. Following this analysis, the evaluation went on to examine whether, despite these shortcomings, these conditions may have contributed to structural reform over time. The evaluation assessed the extent to which structural conditionality contributed to bring about durable changes consistent with the achievement of the program's stated objectives. These objectives extended well beyond the structural conditions prescribed by the programs in the corresponding sectors. Overall, the IEO found only a weak correlation between compliance with structural conditionality and furthering of reforms.

There appears to be some confusion on the evaluation's comments on the role of IMF conditionality in non-core areas. The evaluation found that struc- 
tural conditionality tends to be better designed and to be complied with more often in areas where IMF staff have greater expertise. Conditions in core areas are also more likely to play a catalytic role for further reform. Thus the recommendation to focus conditionality in core areas and to play a subsidiary role in others. The IEO recognizes that in some cases, reforms in non-core areas may be critical for the achievement of program objectives, and that at times this could occur when neither the World Bank nor other multilateral organizations may be focusing on these issues. However, it should be expected that that would be the case for much less than one-third of all conditions - the share of conditions in non-core areas found during the period of this evaluation. It is in these cases where the IEO recommends that further guidance from the Board be sought.

Finally, we welcome the recognition of the "need to undertake outreach that would expand the understanding of civil society and other stakeholders regarding the purposes and confines of Fund conditionality." To do so effectively will require greater clarity from the Executive Board and in operational guidance than currently exists as to the purposes of conditionality and the concepts of criticality and parsimony as set out above. 


\title{
The Chair's Summing Up \\ ieO Evaluation of Structural Conditionality \\ IN IMF-SUPPORTED PROGRAMS
}

\author{
Executive Board Meeting \\ December 12, 2007
}

Executive Directors welcomed the report by the Independent Evaluation Office (IEO) assessing structural conditionality in IMF-supported programs. The report provides a wealth of valuable information. Directors broadly agreed with the IEO's findings, and noted that the IEO assessment gives useful impetus to the ongoing effort to make the Fund more focused and relevant.

\section{Key IEO Findings}

Directors commended the shift in the composition of structural conditionality towards Fund core areas. With fewer areas of reform targeted, there has been progress from comprehensiveness to parsimony in coverage, and a greater focus in program design.

Nevertheless, two important findings of the IEO report suggest that there is scope for further strengthening the implementation of the 2002 Conditionality Guidelines.

\section{Criticality and number of conditions}

Most Directors expressed concern regarding the IEO finding that the number of structural conditions did not decline significantly, and that some structural conditionality may have covered areas not critical to program goals. Many Directors recognized that it is important to consider not only the number but also the quality and coherence of structural conditions included in programs. Some Directors highlighted that criticality needs to be tailored to countryspecific circumstances.

\section{Ownership and potential for fostering future reforms}

Directors took note of the IEO's finding that compliance rates on structural conditionality have been low in many cases, and that often structural conditionality did not spur further reforms. Several Directors did not consider that conditionality should necessarily foster reforms beyond the program objectives. Directors agreed that strong country ownership of programs is essential, and some emphasized that conditions set for non-critical areas when requested by the authorities may serve to enhance ownership. Several Directors advised caution on setting conditions in non-critical areas at the request of donors.

\section{Key IEO Recommendations}

Directors broadly supported strengthened efforts to streamline conditionality, with parsimony as the guiding principle and a focus on measures critical to achieving program objectives. To enhance broad national ownership - and thereby complianceDirectors called for greater reliance on the authorities' views in setting conditions.

\section{A possible "Notional Cap" on the number of structural conditions per year}

Many Directors supported the IEO's call for a notional cap on the number of conditions-flexibly applied-as providing greater discipline in program design, as well as improving the focus and prioritization of conditionality. A majority of the Executive Board, however, saw a cap as overly rigid and mechanistic, which would compound the difficulty of tailoring programs to country-specific circumstances. The preferred way forward appears to be to strengthen efforts to achieve parsimony by focusing on criticality, and requiring rigorous justification for conditions. Better Board scrutiny of programs will be also important. To this end, some Directors reiterated their support for inclusion in program documents of text boxes that lay out the rationale for structural conditions. 


\section{A better articulation of program design and conditionality}

Directors agreed with the IEO that the link between program goals, strategies, and conditions should be better explained in Board papers - and that this should be monitored. In particular, several Directors proposed that initial program requests include a roadmap describing the sequencing and linkage of conditions to stated program goals; some Directors proposed that final program reviews should include a stock-taking to compare stated program goals with their achievement.

\section{Greater outreach}

A number of Directors expressed support for the report's emphasis on greater Fund outreach to explain the purpose of conditionality, within the tight budgetary envelope. Many others, however, emphasized that clearer program documents should be the main vehicle for providing the rationale for the conditions included, and for dispelling misconceptions. Explanation of program measures was seen as the responsibility primarily of national authorities.

\section{A possible elimination of structural benchmarks}

Directors stressed that parsimony and a focus on criticality should apply also in setting structural benchmarks. A majority of the Executive Board did not support the IEO's suggestion to eliminate structural benchmarks, with several Directors noting their importance as markers to assess progress on reforms.

\section{A possible subsidiary role for the Fund in non-} core areas

Most Directors reiterated that-consistent with the 2002 Conditionality Guidelines-Fund conditionality needs to cover all measures critical for program success, regardless of whether they are in core or non-core areas of the Fund, although the focus should be on core areas. Conditionality in non-core areas will require strong justification. In the design and monitoring of conditions in non-core areas, Fund staff should be able to count on the expertise provided by other institutions, notably the World Bank. Directors believed that rigorous implementation of the recently agreed Joint Management Action Plan will be key to resolving issues pertaining to BankFund collaboration on conditionality, and called for strong management leadership in this regard.

$$
* * *
$$

Directors looked forward to consideration of management's implementation plan of the Boardendorsed recommendations in early 2008. 